
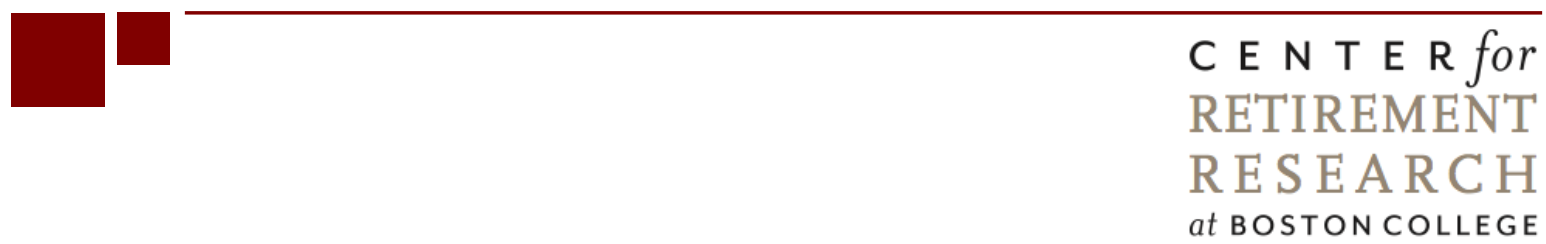

\title{
DO TAX INCENTIVES INCREASE 401(K) RETIREMENT SAVING? EVIDENCE FROM THE ADOPTION OF CATCH-UP CONTRIBUTIONS
}

\author{
Matthew S. Rutledge, April Yanyuan Wu, Francis M. Vitagliano \\ CRR WP 2014-17 \\ November 2014 \\ Revised: July 2016 \\ Center for Retirement Research at Boston College \\ Hovey House \\ 140 Commonwealth Ave \\ Chestnut Hill, MA 02467 \\ Tel: 617-552-1762 Fax: 617-552-0191 \\ http://crr.bc.edu
}

\begin{abstract}
Matthew S. Rutledge is a research economist at the Center for Retirement Research at Boston College (CRR). April Yanyuan Wu is a researcher at Mathematica Policy Research. Francis M. Vitagliano is a research consultant at the CRR. The research reported herein was performed pursuant to a grant from the U.S. Social Security Administration (SSA) funded as part of the Retirement Research Consortium. The opinions and conclusions expressed are solely those of the authors and do not represent the opinions or policy of SSA, any agency of the federal government, or Boston College. Neither the United States Government nor any agency thereof, nor any of their employees, makes any warranty, express or implied, or assumes any legal liability or responsibility for the accuracy, completeness, or usefulness of the contents of this report. Reference herein to any specific commercial product, process or service by trade name, trademark, manufacturer, or otherwise does not necessarily constitute or imply endorsement, recommendation or favoring by the United States Government or any agency thereof. The authors are indebted to the indispensable data analysis of Qi Guan, and would also like to thank Robin Jensen for excellent research assistance. The authors are grateful to Kelly Trageser, Gary Benedetto, and Martha Stinson for helping us access the SIPP synthetic data and re-running our code on the actual data.
\end{abstract}

(C) 2016, Matthew S. Rutledge, April Yanyuan Wu, Francis M. Vitagliano. All rights reserved. Short sections of text, not to exceed two paragraphs, may be quoted without explicit permission provided that full credit, including (C) notice, is given to the source. 


\begin{abstract}
About the Center for Retirement Research
The Center for Retirement Research at Boston College, part of a consortium that includes parallel centers at the University of Michigan and the National Bureau of Economic Research, was established in 1998 through a grant from the Social Security Administration. The Center's mission is to produce first-class research and forge a strong link between the academic community and decision-makers in the public and private sectors around an issue of critical importance to the nation's future. To achieve this mission, the Center sponsors a wide variety of research projects, transmits new findings to a broad audience, trains new scholars, and broadens access to valuable data sources.
\end{abstract}

Center for Retirement Research at Boston College

Hovey House

140 Commonwealth Ave

Chestnut Hill, MA 02467

Tel: 617-552-1762 Fax: 617-552-0191

http://crr.bc.edu

Affiliated Institutions:

The Brookings Institution

Massachusetts Institute of Technology

Syracuse University

Urban Institute 


\begin{abstract}
The U.S. government subsidizes retirement saving through 401(k) plans with $\$ 82.7$ billion in tax expenditures annually, but the question of whether these tax incentives are effective in increasing saving remains unanswered. Using longitudinal U.S. Social Security Administration data on tax-deferred earnings linked to the Survey of Income and Program Participation, the project examines whether the "catch-up provision,” which allows workers age 50 and over to contribute more to their 401(k) plans, has been effective in increasing earnings deferrals. The study finds that annual contributions increased by $\$ 818$ more among age-50-plus individuals constrained by the 401(k) tax-deferral limits relative to similar workers just under age 50, suggesting that constrained individuals respond to tax incentives. For this group, the elasticity of retirement savings to the tax incentive is relatively high: a 1-percentage-point increase in the tax-deferred limit leads to a 0.2 percentage-point increase in $401(\mathrm{k})$ contributions. But barely 1 percent of lower-saving participants took advantage of catch-up contributions, suggesting that raising the $401(\mathrm{k})$ limit is not likely to be a broad-based solution to retirement saving shortfalls.
\end{abstract}




\section{Introduction}

The Joint Committee on Taxation (2015) estimates that the tax-deferred treatment of saving into defined contribution (DC) plans like 401(k)s cost the federal government \$82.7 billion in lost revenue in 2016. But researchers have not come to a consensus on whether this tax expenditure induces additional retirement saving (see Bernheim 2002 for a review). Indeed, whether retirement savings respond to any tax incentive is an open question. Chetty et al. (2014), using Danish data, find that 85 percent of savers are “passive:” their saving rate increases only when it is done automatically. Ramnath (2013) finds no evidence that low-income Americans’ retirement saving increases in response to the Saver's Tax Credit. ${ }^{\text {a }}$

The increase in the maximum tax-deferred 401(k) contribution for participants age 50 and older provides a natural experiment in whether savers respond to a change in the tax incentives. The Economic Growth and Tax Relief Reconciliation Act of 2001 for the first time allowed individuals age 50 and over to make "catch-up contributions” that extend the incentives for older workers. In 2016, the contribution limit is $\$ 18,000$, but older workers can contribute an extra \$6,000 per year. ${ }^{\text {b }}$ The higher limit provides an incentive for workers previously constrained by the maximum to increase their tax-deferred savings but does not change the incentives to save for workers unconstrained by the limit.

Evaluating the effect of the catch-up provision on 401(k) saving requires accounting for three factors: the fundamental differences between maximum contributors (who faced a change in incentives) and participants contributing a lower amount (who faced no change), the growth in 401(k) contributions over time, and the potential increase in saving with age. This study adopts a triple-differences framework, comparing the change in 401(k) contributions for maximum contributors just after age 50 to similar participants just under age 50, within a tight window

\footnotetext{
${ }^{a}$ Much of the literature focuses on whether the deferred taxes in defined contribution plans increase total retirement saving. Poterba, Venti, and Wise (1995) find that 401(k) saving is not offset by decreases in other financial assets. In contrast, Engen, Gale, and Scholz (1994) argue that most of the investment in IRA or 401(k) accounts reflects asset shifting, not new net capital accumulation. Gelber (2011) finds that accumulating enough work experience to become eligible for 401(k) participation raises 401(k) saving, but confidence intervals on the response in other assets are wide, so he cannot definitively conclude that overall retirement saving increases.

b This study uses “401(k)” as shorthand for all defined contribution (DC) plans involving a salary deferral; the U.S. Department of Labor often summarizes these plans as “401(k)-type” plans. Similar catch-up allowances are in place for 403(b) and 457 plans, but these allowances were adopted earlier than for 401(k) plans. The tax records do not distinguish between 401(k), 403(b), and 457 plans, but 401(k) plans make up as much as 87 percent of DC plan enrollment (U.S. Department of Labor 2013). Similarly, “contributions” and "deferrals” are used interchangeably, because all deferrals become contributions.
} 
around the policy change. The identification assumption is that maximum contributors at ages 50-53 are (conditionally) identical to maximum contributors at ages 46-49, except that the older group faces a higher deferral limit. ${ }^{c}$ In that event, the differential increase in contributions for this older group from just before 2002 to just after is due to the adoption of the catch-up provision.

The existing literature documents the two non-policy factors that complicate the analysis. First, contributions have increased over time as workers have lost access to defined benefit pensions and have come to rely on $401(\mathrm{k}) \mathrm{s}$ as the sole source of employer-sponsored retirement saving (Poterba, Venti, and Wise 2008). Second, contributions may rise at age 50 not due solely to tax policy. The life cycle model predicts an increase in retirement saving around age 50, due to a combination of factors, e.g., children graduating from college (Gokhale, Kotlikoff, and Warshawsky 2002). Empirical evidence suggests that saving rates increased around age 50 between 0.5 and 1.2 percentage points, even before the adoption of catch-up contributions (Holden and VanDerhei 2001; Poterba, Venti, and Wise 2008; Joulfaian and Richardson 2001). ${ }^{\mathrm{d}}$

This study estimates the triple-differences model using demographic and economic characteristics from the Survey of Income and Program Participation (SIPP) linked to administrative data on tax-deferred earnings from the U.S. Social Security Administration (SSA). We find that high-saving workers respond to the tax incentives in the catch-up contribution provision. After adoption of the catch-up contribution in 2002, workers age 50 and over constrained by the maximum deferral level increase their contributions by $\$ 818-1,183$ more than the increase by similar workers under 50. This increase is 7-10 percent of the maximum deferral level from before the catch-up provision was adopted (about \$11,700). Adjusting for inflation, the deferral limit increased by 52 percent for participants age 50 and over, or 33 percentage points faster than the simultaneous increase in the limit for participants under age 50 (19 percent; see Table 1). The 7-10 percent increase in contributions represents about 21-30 percent of the 22-percentage-point rise in the limit for the 50+ group; that is, the elasticity of retirement savings

\footnotetext{
${ }^{\mathrm{c}}$ Another challenge is that maximum contributors just under age 50 also faced increasing deferral limits between 2002 and 2005. But because participants age 50 and over faced these same increases - and catch-up contributions on top of them - the triple-differences framework should difference out this increase.

${ }^{d}$ Other research finds that saving accelerates at younger ages, in one's mid-to-late 30s (Love 2007) or mid-40s (Cagetti 2003). Other studies find later acceleration; King and Dicks-Mireaux (1982) and Hubbard (1986) find that the ratio of net worth to permanent income increases into one's 60s, though these studies pre-date defined contribution plans. On the other hand, saving rates may never accelerate; Munnell and Sundén (2004) find a relatively constant 401(k) contribution rate after age 30.
} 
to the tax incentive is in the range of 0.21-0.24, depending on the model specification. Deferrals among maximum contributors just under age 50 - who faced smaller increases in the maximum deferral - also increased by a large and statistically significant amount. These results suggest that contributors near the maximum have excess capacity for further tax-deferred saving and are somewhat sensitive to changes in the statutory limit. But the response to greater 401(k) limits appears to be entirely restricted to high savers: barely 1 percent of individuals in the lower twothirds of cumulative 401(k) saving took advantage of catch-up contributions, compared to about 12 percent of participants in the top third.

The paper proceeds as follows. Section 2 discusses the institutional background behind 401(k) plans and the adoption of the catch-up contribution provision. Section 3 describes the SIPP Completed Data File and outlines the difference-in-differences and triple-differences methodology used in the regression models. Section 4 describes the results, and Section 5 concludes that the catch-up provision increased 401(k) deferrals among maximum contributors, demonstrating the sensitivity of their retirement saving to tax incentives, but is not likely to provide a broad-based solution to the retirement saving shortfall for other workers.

\section{Background: 401(k) Pensions and the Catch-Up Contribution}

Although deferred compensation plans had existed for several decades, the Employee Retirement Income Security Act (ERISA) of 1974 set in motion the creation of the 401(k) pension plan, named after Section 401(k) of the IRS Code, which sanctions the use of salary reductions as a source of plan contributions. The law went into effect on January 1, 1980.

The Tax Reform Act of 1986 added a separate limit (IRS Code 402(g)) for salary deferral contributions into 401(k) plans. Previously the only limit on salary deferral contributions was the total defined contribution limit of $\$ 30,000$ (in 1986) set by IRS Code 415. The 402(g) deferral limit was originally set at $\$ 7,000$ and indexed to inflation thereafter.

The Economic Growth and Tax Relief Reconciliation Act in 2001 increased potential contributions in two ways. First, starting in 2002, the participant salary deferral limit was increased by $\$ 1,000$ per year until reaching $\$ 15,000$ in 2006; this increase exceeded the inflation adjustments previously in place. After 2006 the limit was indexed to inflation. Second, to further encourage retirement savings by older workers, the federal government added catch-up contributions to 401(k) plans, allowing participants age 50 or older to make additional salary 
deferral contributions into their 401(k) accounts. The limit on catch-up contributions into 401(k)s was \$1,000 in 2002 and increased \$1,000 per year until reaching \$5,000 in 2006. e Raising these limits was sold as an attempt to increase retirement saving. Sen. Rob Portman (R-Ohio), the bill's leading proponent, cited concerns among business owners that low limits made them less likely to offer plans. He promoted the ability for all workers - but in particular women who had spent time out of the labor force when their children were young - to make up for low savings in past years (Johnston 2001).

Table 1 reports 401(k) contribution limits for 1999-2005 in nominal and real (2005) dollars by age, demonstrating how catch-up contributions allowed the maximum deferral to increase rapidly for participants approaching retirement. Adjusting for inflation, the deferral limit increased by 5.3 percent per year from 2002-2011 for participants age 50 and over, 2.2 percentage points of which is due to speeding up the increase in the limit for all ages. The catchup provision increased the real limit by the remaining 3.1 percentage points.

In 2016, the maximum 402(g) elective deferral amount is $\$ 18,000$. The maximum $414(\mathrm{v})$ catch-up amount is $\$ 6,000$. The total employer and employee contributions permitted in a DC plan (415 limits) for any participant is $\$ 53,000$. Thus an age-eligible participant might be able to contribute a total of $\$ 24,000$ in salary deferrals into his $401(\mathrm{k})$ account and receive an additional $\$ 29,000$ of employer contributions and/or match contributions.

Salary deferral contributions are tax deductible to the worker when made, lowering the worker's tax liability in that year. The worker pays taxes when distributions of 401(k) funds are made to him. The worker may be liable for early distribution tax penalties of $10 \%$ if the distributions are made before age $59 \frac{1 / 2 .}{.}$ The working-age participant benefits from this arrangement in several ways. First, the increase in the tax burden is in the uncertain and heavilydiscounted future, while the reduction in the tax burden is in the present. Second, the government essentially gives the participant an interest-free loan for the tax burden, which the participant can reinvest to build up a larger 401(k) balance (Gokhale, Kotlikoff, and Warshawsky

\footnotetext{
${ }^{\text {e }}$ It is important to note that the catch-up contribution amounts (IRS Code 414(v)) are not subject to nondiscrimination tests (Prudential 2003). This allows for the age-eligible highly compensated participants to take full advantage of the catch-up contributions, notwithstanding any plan constraints due to the non-discrimination testing and limits. Because we do not know which participants are constrained by the non-discrimination tests, some participants in the non-max-contributor group will be constrained before the catch-up limit and not constrained afterward, biasing our results toward not finding an effect of raising the catch-up limit on 401(k) contributions. ${ }^{\mathrm{f}}$ The penalty does not apply if the employee separates from the firm at or after age 55.
} 
2002). Third, the participant benefits if his future tax burden is calculated from a lower marginal tax rate when the funds are withdrawn than when they are earned. ${ }^{g}$

A few existing studies have evaluated the catch-up provision but fail to reach a consensus on whether this provision induces additional retirement saving. The potential gain in 401(k) saving may be small because, as Orszag (2004) reports, only 5 percent of individuals in the 2001 Survey of Consumer Finances were bound by the maximum. Similarly, Kawachi, Smith, and Toder (2005) find that only 7.5 percent of participants contributed the IRS maximum in 2001, with that proportion actually decreasing in 2002 and 2003 as some older households chose not to take advantage of the catch-up provision. In contrast, Holden et al. (2005) suggest that after the catch-up provision was adopted for Individual Retirement Accounts (at the same time as 401(k) plans), one-third of previously constrained older households took advantage of the higher limits, and each of those households in their sample contributed precisely the maximum. These analyses of retirement saving around the time that catch-up provisions were adopted are largely descriptive and do not attempt to measure the causal increase in contributions among contributors near the maximum.

The only other study to examine the change in 401(k) saving induced by the change in tax incentives from the adoption of catch-up contributions is Lavecchia (2015). ${ }^{\mathrm{h}}$ That study uses self-reported 401(k) contributions from the public-use version of SIPP, finding no statistically significant evidence of a change in 401(k) saving with the introduction of catch-up contributions. Because of data limitations, Lavecchia does not separate max and non-max contributors; because they are unconstrained, non-max contributors will have the same tax incentive to save in both periods, attenuating the effect of the higher limit. The unconstrained will only be affected by catch-up contributions indirectly - for example, Lavecchia cites financial industry literature urging members to reach out to non-max contributors, but whether education efforts and

\footnotetext{
${ }^{g}$ Our study focuses on traditional 401(k) plans, as the data is limited to tax-deferred contributions. In recent years workers have had access to Roth $401(\mathrm{k})$ plans, where contributions are post-tax, but withdrawals are never again taxed - effectively making earnings on those plans tax-free. Munnell, Quinby, and Webb (2012) emphasize that if the participant faces the same marginal tax rate pre- and post-retirement and the discount rate equals the market rate of return, traditional and Roth 401(k) plans yield the same after-tax value. The comparison to taxable accounts discussed above holds for either 401(k) type, but the data limit our analysis to traditional plans.

${ }^{\mathrm{h}}$ Milligan (2003) examines a similar increase in the limits for tax-preferred retirement accounts in Canada. Milligan focuses on how households respond to higher contribution limits in the future, finding that current contributions fall in anticipation.
} 
"nudges” would be enough to induce lower savers to actually contribute more is unclear. ${ }^{\mathrm{i}}$

Our study uses administrative data that should be a more accurate measure of deferred earnings than would be available in a household survey alone, while connecting this administrative data to detailed information on demographics and economic circumstances not available in administrative data alone. The results of this study add to our understanding of the effects of tax incentives on saving.

\section{Data and Methodology}

This study uses the SIPP Synthetic Beta (SSB), a data product that allows users to link the SIPP household survey to administrative earnings records without requiring access to the restricted data (Abowd, Stinson, and Benedetto 2006).

In the public-use SIPP, each individual in a household is interviewed every four months over the two to five years in their panel about a wide range of topics, including labor market outcomes, public program participation, demographics and family structure, and health insurance coverage. A subset of essential SIPP variables is then linked, via Social Security Number, to an SSA-produced extract from W-2 tax records, including an individual's total annual tax-deferred earnings for each year from 1978-2011; this study examines a smaller window of tax records: three years before the adoption of the catch-up provision (1999-2001), the year of its adoption (2002), and nine years after its implementation (2003-2011). ${ }^{j}$

The SSB alleviates privacy disclosure concerns by allowing researchers to first run their analysis on synthesized data and then re-run the analysis on actual data. The synthesis first involves imputing missing values for a subset of essential SIPP variables to create four implicates called the SIPP Completed Data Files, each the result of separate imputations. Finally, each variable in each implicate - with the exception of gender, spouse's identifier, and type of Social Security benefit - is synthesized four times to create a total of 16 SSB implicates. The synthetic data aim only to match unconditional means of the public-use SIPP variables, so

\footnotetext{
${ }^{\mathrm{i}}$ Unlike with 401(k)s, Lavecchia (2015) does find a statistically significant but small (about 23 percent) increase in IRA contributions, which he attributes to the more attainable limit for IRAs: the tax-deferred IRA contribution limit was raised from only \$2,000 in 2001 to $\$ 4,000$ for savers under 50 and \$5,000 for savers 50 and older in 2006.

j The SSA Detailed Earnings Record file separately records FICA-taxable and non-FICA earnings. This study uses the total deferred earnings, i.e. the sum of the FICA and non-FICA deferred earnings variables. The Summary Earnings Record, also available via the SSB, contains earnings up to the FICA taxable maximum dating back as far as 1951. All results are comparable if we had instead used earnings records only through 2005.
} 
conditional analysis for selected subsamples is not meaningful. With this consideration, the results reported in this paper are the average of the estimates produced from the four implicates of the Completed Data Files; other than imputed values, therefore, the analysis uses actual, rather than synthetic, data. ${ }^{\mathrm{k}}$

The sample includes any working individual matched to the SSA earnings records who was age 46-53 at some point between 1999 and 2011, even if that individual was sampled by the SIPP outside of that window (Table 2). ${ }^{1}$ The primary sample excludes individuals who failed to accumulate enough earnings to qualify for four credits toward SSA “insured status” in every year in which they were age 46-53 between 1999 and 2011. ${ }^{\mathrm{m}}$ This restriction eliminates many workers with low or inconsistent earnings who are less likely to be offered a 401(k), less likely to be eligible to participate, or less likely to contribute even if they were eligible (Wu and Rutledge 2014). ${ }^{\mathrm{n}}$ The sample further excludes anyone reporting the inability to work due to a health condition while they were sampled by the SIPP, as individuals with work-preventing health conditions may save more to make up for the risk of an earlier retirement, or are less able to save due to diminished earning capacity. ${ }^{\circ}$

The dependent variables $(y)$ in the regressions are, separately, individual $i$ 's annual total tax-deferred earnings in 2005 dollars (adjusted by the Consumer Price Index for all urban consumers), or the contribution rate, i.e., the ratio of total deferred earnings to total earnings in year $t$. The regression is a linear triple-differences model, where the more basic specification is of the form:

$$
\begin{aligned}
& y_{i t}=\alpha_{0}+\alpha_{1} C U C_{t}+\alpha_{2} A g e 50_{i t}+\alpha_{3} \operatorname{Max}_{i t}+\alpha_{12} C U C_{t} A g e 50_{i t}+ \\
& \alpha_{13} C U C_{t} \operatorname{Max}_{i t}+\alpha_{23} \text { Age } 50_{i t} \operatorname{Max}_{i t}+\alpha_{123} C U C_{t} A g e 50_{i t} \operatorname{Max}_{i t}+\gamma^{\prime} X_{i t}+\tau_{t}+v_{i t},
\end{aligned}
$$

\footnotetext{
k SSB results are available upon request.

${ }^{1}$ Most of the control variables in the regression model are time-invariant for middle-aged individuals, including education, marital status, and children's ages. Other variables, including net worth quartiles, pension coverage, and blue collar status, are from the specific SIPP interview and should be interpreted with caution; e.g., the coefficient on blue-collar should be interpreted as "those who reported working blue collar at one time."

${ }^{\mathrm{m}}$ Workers earn as many as four "quarters of coverage” or "credits” per year for every multiple of a specific threshold of FICA-taxable earnings. That threshold is adjusted annually to account for wage inflation. In 1999 (2005), a worker earned one credit for every multiple of $\$ 740$ (\$920) of earnings, up to the maximum of four credits. Our employment variable marks someone as a non-worker even if they earned as much as $\$ 2,960-\$ 3,680$ (nominal) in a year, but anyone earning less than this level is very unlikely to be eligible for, or take up, a pension plan. $\mathrm{n}$ The results are robust to the inclusion of any individual earning at least four credits in the given year.

${ }^{\circ}$ All analyses are unweighted, as the SIPP Synthetic and Completed Files do not include weights that account for the possibly-unrepresentative match to the SSA data.
} 
The basic difference-in-differences regression variables are: 1) $C U C_{t}$, an indicator variable equal to one if the catch-up contribution has been adopted (i.e., $t \geq 2002$ ); and 2) $A g e 50_{i t}$, an indicator variable equal to one if $i$ is age 50 or older in year $t$, and hence eligible for catch-up contributions if the provision is in place.

The other important variable is $\operatorname{Max}_{i t}$, an indicator variable equal to one if the individual has any years in which he contributed within 10 percent of the maximum at any previous age, to reflect that these individuals had been constrained (or close to it). This variable allows for tolerance around the actual limit because not all workers will be able to hit their limit exactly if their earnings change within the year.

The regression model includes a complete set of interactions between these three variables. A positive and statistically significant coefficient on the triple interaction $\left(\alpha_{123}\right)$ indicates that previously constrained participants increase their contributions at age 50 by more than maximum-contributors under 50 after the adoption of the catch-up provision. ${ }^{\mathrm{p}}$

In both specifications, $\tau$ is a series of year dummies. $X$ is a vector of personal characteristics including gender, race, Hispanic origin, educational attainment, being foreign born, marital status, having a working spouse, earnings terciles, net worth quintiles, homeownership, working in a blue-collar occupation, Census geographic region, and calendar year. Because parents may reduce their 401(k) contributions while their children are in college, $X$ includes an indicator for the presence of children between the ages of 18 and 24, as well as an indicator for having children under 18, which either reduces the ability to save relative to nonparents or parents of kids above 24 or increases the incentive to save in anticipation that the parents will miss contributions during the college years. Finally, $X$ includes indicators representing whether the individual reports having a defined benefit (DB) pension or defined contribution (DC) pension at their current job during his SIPP sampling window. Because the timing of the information on pension type does not necessarily correspond to the 1999-2011

\footnotetext{
$\mathrm{p}$ The coefficient on the interaction of age 50+ and post-2002 $\left(\alpha_{13}\right)$ may be of interest on its own; this coefficient would indicate whether those who have not been constrained by the legal deferral limit increase their contributions at age 50 by more after the catch-up provision, perhaps because of increased outreach efforts from their 401(k) providers or employers anticipating increases in funds cycling through the pension system. See Lavecchia (2015) for further discussion.
} 
window for deferred earnings, these variables should be interpreted as "ever having a DB" or "ever having a DC." q

We also estimate a more flexible functional form with respect to age:

$$
\begin{aligned}
& y_{i t}=\alpha_{0}+\alpha_{1} \text { CUC }_{t}+\alpha_{2} \operatorname{Max}_{i t}+\alpha_{12} \text { CUC }_{t} \operatorname{Max}_{i t} \\
& +\sum_{a=47}^{53}\left(\beta_{1 a} D_{i a t}+\beta_{2 a} D_{i a t} C U C_{t}+\beta_{3 a} D_{i a t} \operatorname{Max}_{i t}+\delta_{a} D_{i a t} C U C_{t} \operatorname{Max}_{i t}\right) \\
& +\gamma^{\prime} X_{i t}+\tau_{t}+v_{i t},
\end{aligned}
$$

$D_{\text {iat }}$ is equal to one if the individual $i$ is age $a$ in year $t$; the omitted age is 46 . The coefficients of interest in this specification are $\delta_{a}$ 's. We test whether each individual $\delta_{a}$ is statistically distinct from zero, and whether the sum of $\delta_{50}+\delta_{51}+\delta_{52}+\delta_{53}$ is statistically distinct from the sum of $\delta_{47}+\delta_{48}+\delta_{49}$, which indicates that $401(\mathrm{k})$ contributions increased differentially for catch-up eligible individuals after the adoption of the catch-up provision. The omitted category is age 46.

Finally, we estimate a specification where $A g e 50_{i t}$ and $\operatorname{Max}_{i t}$ are interacted with each year dummy, to graph the regression-adjusted time trend in $401(\mathrm{k})$ contributions and contribution rates among max contributors age 50 and older relative to max contributors under age 50 . This time trend is presented to take into account the slow adoption of higher catch-up limits among plan administrators and the time it took for participants to realize they were eligible for greater contributions after their $50^{\text {th }}$ birthdays.

\section{Results}

Figure 1 displays average, real 401(k) contributions by age and time period for workers ages 46-53 who are never observed approaching the deferral limit between these ages. ${ }^{r}$ Deferred earnings for this group increase gradually with age before the catch-up limits are in place. After the catch-up limit is implemented, the increase with age becomes slightly steeper, particularly in

\footnotetext{
${ }^{q}$ Unfortunately, the SSB does not include an indicator for whether the individual has had a DB pension from a previous job. Individuals who can count on significant DB pension income will be less inclined to contribute to 401(k) plans in their later-career jobs. Limiting our sample to workers age 46-53 likely eliminates many early retirees and individuals who switch to "bridge jobs" because they no longer need to accrue DB pension benefits, and most workers who have had a DB pension only through jobs they held before age 50 will not have accumulated a significant DB pension, and so 401(k) contributions are still attractive.

${ }^{r}$ This criterion differs from the indicator from the regression analysis, which is equal to one if the individual was at or near the maximum at any earlier age.
} 
the years in which catch-up contributions are made possible. At ages 46-49, the difference between the two periods averages $\$ 57$ (in 2005 dollars); at ages 50-53, the difference between the periods averages $\$ 255$. The slight increase in deferred earnings makes sense, given that this period DC pension plans continued the gradual replacement of DB plans. The greater increase at ages 50-53 would seem to contradict economic theory, which predicts that unconstrained savers would not be influenced by a higher deferral limit. But Lavecchia (2015) finds evidence that 401(k) and IRA providers, stirred to action by the introduction of catch-up contributions in both vehicles, expended extra effort to reach out to all policyholders age 50 and older - regardless of contribution level - with nudges to contribute more. Figure 1 suggests that these efforts may have raised contributions, but if so, only slightly.

Among maximum contributors under age 50, annual real contributions rose by approximately \$2,500 on average between 1999-2001 and 2002-2011 (Figure 2). But the over50 max contributors saw an even larger increase: over $\$ 5,700$. The jump in contributions was especially large right at age 50 : while contributions rose by $\$ 2,450$ at age 49 , they increased by almost \$6,300 at age 50, an unconditional difference-in-differences of over \$3,850 (in 2005 dollars). At older ages, the increase waned slightly, but remained comfortably larger than the contribution level before the 2002 increases.

Figure 3 plots average 401(k) contributions for max and non-max contributors under 50 and 50 and older by year. Before 2002, the red and gray lines are almost imperceptibly different, ${ }^{\mathrm{s}}$ suggesting that contributions did not increase appreciably with age when both age groups were subject to the same limits. At and after 2002, however, the red lines are above the respective gray lines for each group, indicating that contribution levels increased by more for the 50-plus group, especially max contributors. As the catch-up provision increased in value the (inflation-adjusted) gap between max contributors under 50 and 50 and older kept growing, reaching nearly $\$ 3,600$ in 2006 . The growth near the end of the period reflected increased knowledge on the part of savers and financial planners, but also the fact that some plans were slow to allow its age 50-plus participants to contribute more than the under-50 limit. ${ }^{t}$

\footnotetext{
${ }^{\mathrm{s}} \mathrm{A}$ Heckman and Hotz (1989) regression of an indicator for inclusion in the treatment group (being observed at 5053) on the characteristics of individuals before age 50 finds that nearly every coefficient is statistically significant, but the magnitudes are small, so treatment and control groups should be sufficiently similar for the difference-indifferences analysis to be valid.

${ }^{t}$ The authors thank Jean Young of Vanguard, David Richardson of TIAA-CREF, and Sarah Holden of ICI for pointing out this structural limitation. Lavecchia (2015) also cites industry reports referring to incomplete adoption.
} 
These figures lay out how contributions changed around the time in which catch-up limits became available, among the people most likely to be affected. But comparisons like these between max and non-max contributors are potential problematic because these two groups differ in notable ways. Table 3 reports summary statistics comparing max contributors to the full sample of participants. Almost 9 percent of participants in our sample have ever contributed within 10 percent of the deferral limit for individuals of their age. ${ }^{u}$ Mean earnings for the full sample are about $\$ 60,000$, of which approximately $\$ 2,400$ is contributed to a DC plan. Max contributors' earnings are nearly $\$ 165,000$ on average; they contribute almost $\$ 10,000$ in the average year to their $401(\mathrm{k}) \mathrm{s}$. Net worth is measured with noise, ${ }^{\mathrm{v}}$ but even with this caveat, it is clear that max contributors have greater wealth at their disposal: almost $\$ 475,000$, compared to $\$ 215,000$ for the full sample. Max contributors are more likely to be male, married, white, and have at least a college degree, and are less likely to have children under 24 or a work-limiting health condition. Interestingly, max contributors are slightly more likely to be blue-collar workers, perhaps reflecting greater saving rates among union members who may have been accustomed to generous DB pension benefits. They are also slightly more likely to be foreign born or a race other than white or black, reflecting greater saving rates among immigrants and Asian-Americans. ${ }^{\mathrm{w}, \mathrm{x}}$

The linear regression model formalizes the comparison of deferred contributions over time by age. Table 4 reports the results from the simpler specification (equation 1). ${ }^{y}$ The sample is limited to individuals who earn four credits in each of the years between 1999 and 2011 in which they were ages 46-53. The first column reports the results from the model where the

\footnotetext{
" Vanguard (2015) reports that about 10 percent of participants saved the statutory maximum in 2014, and that this group is disproportionately high-income with higher accumulated balances.

${ }^{\mathrm{v}}$ Unlike 401(k) contributions, which derive from administrative data, information on net worth is self-reported, which is almost certainly less reliable. Furthermore, we do not limit the sample to individuals who are sampled by the SIPP at the time that they are 46-53, so the survey year may not line up with the years in which we are interested in their 401(k) contributions.

${ }^{\text {w }}$ See Benjamin, Choi, and Strickland (2010) for a review of saving preferences among race and nativity.

${ }^{x}$ The differences in observable characteristics between the pre- and post-catch-up periods by age are similar to the differences in the overall sample: earnings and net worth fell between periods but increase with age, and changes between periods in demographics and family structure are consistent with overall trends. Unconditional differences by age, time period, and max vs. non-max contribution status are available upon request.

${ }^{y}$ The difference-in-differences estimate in a regression that ignores whether the worker has been previously constrained by the tax-deferred limit is small and statistically insignificant, and of a similar magnitude to Lavecchia (2015), who estimates a similar regression using self-reported 401(k) contributions. But identification of the effect of catch-up limits on 401(k) contributions is only valid among max contributors, who are hard to identify without administrative data.
} 
dependent variable is the real annual 401(k) contribution level. The second column reports estimates where the dependent variable is the $401(\mathrm{k})$ contribution rate (i.e., the ratio of deferred earnings to total earnings).

The triple-differences model finds a statistically significant increase in contributions among workers 50 and older after the adoption of the catch-up provision relative to workers just under 50 . The changes in $401(\mathrm{k})$ contributions implied by the model are summarized graphically in Figure 4.

The two bottom bars of Figure 4 represent the workers not constrained by the deferral limit. Both of these groups increase contributions by only a small but statistically significant amount after the adoption of the catch-up provision. The interaction between the indicators for age-50-plus and 2002-and-later is statistically insignificant, small, and positive, suggesting that workers over 50 in the latter period contribute almost exactly the same as under-50 workers in that period: \$192 and \$329, respectively.

As expected, the story is much different for those workers near the maximum (the top two bars of Figure 4). Max contributors under age 50 defer a statistically significant $\$ 1,166$ more after 2001 than non-max contributors in the same age group, for a total additional contribution of $\$ 1,358$. This increase reflects that the contribution limit was increasing faster than inflation for all ages.

The largest increase was for max contributors who were 50 and over. Their contribution increased by $\$ 2,313$ in total, or a statistically significant $\$ 818$ more than similar workers just under age 50. This increase is 28 percent of the mean and 8.9 percent of the average maximum deferral level from before the catch-up provision was adopted - about \$11,700 in 2005 dollars (Table 1). Adjusting for inflation, the deferral limit increased from an average of $\$ 11,737$ in 1999-2001 to $\$ 17,852$ in 2002-2011, an increase of 52.1 percent for participants age 50 and over. Participants under age 50 saw the limit increase only to $\$ 13,942$ on average from 2002-2011, or 18.8 percent over the 1999-2001 average. So the older group's limit increased by 33 percentage points faster than the simultaneous increase in the limit for participants under age 50 . The 8.9 percent increase in contributions represents 21 percent of the 33-percentage-point rise in the limit for the 50+ group; that is, the implied elasticity of retirement savings to the tax incentive is 0.21 . 
These results suggest that those contributors near the maximum are somewhat sensitive to the change in tax incentives. ${ }^{\mathrm{z}}$

The triple-interaction coefficient when the outcome is the deferral rate is also statistically significant - the increase after 2001 for age-50-plus max contributors is 0.9 percentage points greater than for max contributors under 50 . The magnitude of this difference is only slightly smaller relative to the mean (a 4.2 percent average contribution rate) than the contribution level estimate. Other coefficients are similar to the deferral amount estimates; notably, contributions also increase by a statistically significant 0.4 percentage points among max contributors age 4649 after 2002.

Other estimates in Table 4 are largely consistent with predictions. The highest earners and workers with high wealth contribute more, as do married workers. Having children is associated with lower contributions not just when the child is college-aged, but during their precollege years. Rather than being lower because $401(\mathrm{k})$ wealth is less necessary for people with a DB pension, their contributions and the deferral rate are actually statistically significantly higher, suggesting either that these workers may select into jobs with generous pension benefits or that DB pension holders earn higher wages (though the regression model includes the earnings tercile). In results that are suppressed for space, contributions and deferral rates are larger with more education, are lower for blacks, and are higher among races other than black or white.

The results in Table 5 allow for separate estimates of 401(k) contributions at each age between 47 and 53, relative to contribution levels or rates at age 46 (the omitted condition). For brevity, we report just the coefficients for age and its interactions, but other variables have coefficients that are similar to the results in Table 4.

These results tell a story that is very consistent with Table 4 and with the predictions of economic theory. Individuals who have never been near the maximum deferral level contribute only slightly more after 2002 than they did before 2002, but only if they are age 52-53; workers age 50-51 may also be receiving mailings about the catch-up limit, but their response is not statistically significant.

\footnotetext{
${ }^{\mathrm{z}}$ The results are similar when we limit the sample to the window between 1999 and 2005. The marginal increase in deferrals for max-contributors over age 50 is smaller (\$543) and statistically significant at a lower confidence level. The smaller magnitude demonstrates that the effect increased in later years, as documented in Figure 6a. But the estimated elasticity is almost exactly the same (0.21) because the limit increased by only 22 percentage points more at ages 50+ than under age 50 over the 2002-2005 period.
} 
Workers who have been at the maximum, on the other hand, contribute differentially more after 2002 when they are 50 and over, as we would expect if they were reacting to the implementation of the catch-up provision. The age-50-plus triple-interaction coefficients in Table 5 - and graphed in Figures $5 \mathrm{a}$ and $5 \mathrm{~b}$ - are each statistically significantly different from the omitted condition (2002-and-later contributions made by 46-year-olds who have been near the maximum). The 50-plus coefficients are collectively statistically significantly greater than the sum of the triple-interaction coefficient at ages 47, 48, and 49. Furthermore, the coefficients are large: these workers defer \$853-\$1,418 more after catch-up contributions become available than similar individuals defer before 2002, or 9.1 percent of the average real maximum deferral level from before the catch-up provision was adopted. At the same time, the triple interactions for ages 47 through 49 represent a 1.5 percent increase over the mean, relative to age 46 . This 7.6-percentage-point difference represents 35 percent of the 22-percentage-point increase in the maximum deferral level, implying an elasticity of 401(k) contributions with respect to the deferral limit of 0.23 . This estimated elasticity is just slightly more than the 0.21 implied by the results in Table 4.

Figures $6 \mathrm{a}$ and $6 \mathrm{~b}$ report results from regressions that interact each year indicator with indicators for being a max contributor in a previous year and with an indicator for having reached age 50. The regression-adjusted average contribution for max contributors 50 and older increased by $\$ 359$ (or 0.5 percentage points) in 2002, but this estimate’s confidence interval is too wide to rule out the null hypothesis of no response. In 2003, the marginal increase in the contribution rate was a statistically significant 1.0 percentage points (Figure 6b), but the marginal increase in the contribution level did not become statistically significant until 2004 (Figure 6a). The delayed response to catch-up limits is consistent with the slow adoption of higher post-50 contribution limits discussed earlier. ${ }^{\text {aa }}$

By 2005, max contributors defer substantially higher levels and rates at and after age 50 relative to max contributors under 50. Between 2005 and 2007, this marginal increase is \$940$\$ 990$ in each year, or 1.3-1.6 percent of these workers’ earnings. The gap between max contributors over and under 50 shrunk in 2008 - due to the Great Recession - just enough to lose

\footnotetext{
aa Interestingly, Lavecchia (2015) finds evidence that IRA contributions rose in 2002-2004 in large part because 401(k) participants were not able to take full advantage of the 401(k) catch-up limit. The IRA contribution increase wanes thereafter once more 401(k) plans start permitting higher contributions, though because that study uses selfreported $401(\mathrm{k})$ contributions, the estimate of the $401(\mathrm{k})$ contribution increase is noisy.
} 
statistical significance, but recovered most of this slippage in subsequent years. The elasticity implied by the response just from 2005-2011, and excluding 2008, is 0.24, just slightly larger than the elasticity using the full 2002-2011 period.

The regression results find a substantial response among constrained 401(k) participants to the higher contribution limit after age 50. Max contributors under age 50 also raised their contributions, which is also likely a response to the 401(k) limit rising faster than inflation. The coincident increase among unconstrained savers is statistically significant, but small and hard to attribute credibly to the increase in the 401(k) deferral limits. The aim of the 401(k) limit increase was to expand retirement saving, particularly for women. But given that max contributors are disproportionately high-income and high-wealth, these estimates seem to suggest that the increase in 401(k) saving occurred only among those individuals who least need a boost to retirement saving, and who may only be reallocating saving from taxable to taxdeferred vehicles.

The longitudinal nature of the deferred earnings data allows for the estimation of a fixedeffects regression, where the individual's contribution in any given year - in particular, after catch-up contributions become available - is compared to his average contributions over the sample window. The triple-differences coefficient in the contribution level regression in Table 6 is almost 50 percent larger than the estimate in Table 4 and is strongly statistically significant. The \$1,183 increase in contributions in 2002 and later for workers age 50-53 relative to workers who are just under 50, is 10.1 percent of the maximum deferral, implying an elasticity of 0.30 , slightly larger than the 0.21-0.24 elasticities estimated without individual fixed effects. The triple-differences coefficient in the contribution rate regression in Table 6, on the other hand, is almost exactly equal to the estimate from Table $4 .{ }^{\text {bb }}$ Other estimates are similar, except that the interaction of the ever-at-maximum and post-2002 indicators is small and statistically insignificant, implying that max contributors age 46-49 have no discernible increase in their contributions after the adoption of catch-up contributions once we account for their own tendency to contribute.

\footnotetext{
${ }^{\mathrm{bb}}$ Because the fixed effects regression models do not include time-invariant characteristics, observations that were dropped from the regressions in Tables 4 and 5 with missing values for these characteristics are restored in Table 6 , resulting in a larger sample size, but a qualitatively similar conclusion.
} 


\section{Who Benefited from Catch-Up Contributions?}

Table 7 attempts to examine more directly who benefits from the catch-up limit. Though not much information is available on wealth or movement between taxable and tax-deferred vehicles, the longitudinal record of 401(k) contributions allows us to calculate whether individuals with a history of greater contributions were more likely to raise their deferrals around the time of the limit increase. The entries in Table 7 are the shares of participants who either contribute more than the under-50 limit or increased their contribution from the previous year by about the same as the catch-up limit; the latter condition accounts for workers who would have been max contributors but were restricted to a lower contribution rate by discrimination tests. ${ }^{\text {cc }}$

The (unconditional) results in Table 7 indicate that 7 percent of participants age 50 and older took advantage of the catch-up limit. Contrary to the stated aim of lawmakers to increase saving among women who had been out of the labor force during childrearing years, the share of older men taking advantage of the limit was almost double the share of older women doing the same. Participants are further split into terciles by their cumulative contributions in prior years. Hardly anyone among the lowest two-thirds of participants by this measure took advantage of the catch-up limit (just over 1 percent). Better savers, however, were much more likely to do so: about 14 percent of men and 10 percent of women in the top third of prior contributions raised their deferrals over the under-50 limit or by the amount of the catch-up increase. These results suggest that most of the benefits to the catch-up limit flowed to the group which was already contributing the most.

\section{Robustness Checks}

Table 8 tests the robustness of the triple-difference results on selected sub-samples: by gender, educational attainment, the age of the workers' children, and net worth. The smaller samples make some of the triple-differences coefficients fall just short of statistical significance, but most are significant and the magnitudes are on the same scale as the overall results.

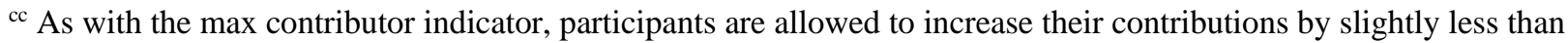
the catch-up limit: if it rose by $\$ 1,000$, we mark anyone who increased their contributions from the previous year by $\$ 950$ as taking advantage of the catch-up limit. Due to small sample sizes, Census disclosure rules restrict us from reporting separate shares of 1) participants over the under-50 limit and 2) those raising their contributions by about the same as the catch-up limit; instead, these groups are aggregated together.
} 
One goal for the catch-up provision mentioned by policymakers was to allow women who may have had their careers interrupted by caregiving to make up for non-contributing years (Johnston 2001). The estimates in the first two rows of Table 8 suggest that women were, indeed, more sensitive to the tax incentives; age-50-plus women who were already maximum contributors increased their $401(\mathrm{k})$ saving by $\$ 991$ more than women under 50, compared to a relative increase of $\$ 716$ for men. But these estimates are unlikely to be statistically significantly different from each other. ${ }^{\text {dd }}$ Furthermore, the total increase in contributions relative to before 2002 (that is, the sum of the same coefficients that we added together in Figure 4) is actually slightly larger for men $(\$ 2,368)$ than for women $(\$ 2,281)$, but these numbers are too similar to be conclusive (and do not isolate the groups' responses to the tax incentives).

Table 8 also includes estimates by the age of the worker's children. The increase in saving for age-50-plus max contributors after 2002 is largest for families with children over age 24. This result suggests that some high-saving families may use the catch-up provision to make up for years when they had to support their children (e.g., with college costs), though Dushi et al (2015) find an increase of only 0.3-1.0 percentage points in the 401(k) contribution rate after the youngest child leaves home.

Not surprisingly, the better educated are more sensitive to the change in the tax incentives starting in 2002 than people with no college experience; even controlling for income and net worth, workers with at least some college education are more likely to be informed about the law, as well as with the benefits of 401(k) saving more generally (Table 8). More surprising is that the triple-differences effect is almost exactly equal for workers above and below the median net worth level, and only the below-median group has a statistically significant estimate, though net worth is self-reported and may have been collected outside of the 1999-2011 window used in this study.

One potential concern is that contributions rise after the catch-up provision was adopted because earnings are also rising. This concern is particularly acute for the high-earning individuals who tend to contribute near the maximum, given the increase in compensation near the top of the earnings distribution. But all employees may see earnings increases because of the

\footnotetext{
dd In our main specification (Table 4), women contribute a statistically significant \$361 more per year than men. We did not estimate a model that fully interacts women with our triple-differences indicators to formally test the statistical significance of the differences in the first two rows of Table 8, given the size of the standard errors.
} 
transition from DB to DC plans: if employees' total retirement plan accrual is held constant throughout the transition, reported earnings would rise, because the $\mathrm{W}-2$ total earnings measure includes employee DC contributions, but not DB accrual. Table 9 repeats the analysis with total real earnings (including employee contributions to tax-deferred plans) as the dependent variable. Real earnings are statistically significantly larger at and after 2002 by about $\$ 2,400$, and the results confirm that max contributors have much higher earnings, by about $\$ 135,000$ per year.

But there is no evidence that earnings grows faster for 50-plus individuals, nor among workers who have previously contributed near the maximum; the coefficients are large, but even in a large sample with presumably-accurate administrative earnings reports, the standard errors are even larger, and not all of the relevant interactions are even positive. The results suggest that the increase in 401(k) contributions was not the mechanical consequence of a rise in earnings; instead, it appears to be a deliberate response to the tax incentive to save.

\section{Conclusion}

This paper examines whether the catch-up provision, which allows workers over 50 to contribute more to their 401(k) plans, has been effective in increasing 401(k) saving. Our results suggest that workers over age 50 constrained by the maximum deferral level increase their contributions by about $\$ 818-1,183$ more than the increase by similar workers under 50 (who also contribute more in response to higher deferral limits). The older group is somewhat sensitive to the change in tax incentives: the elasticity of retirement savings with respect to the tax deferral limit for this group is $0.21-0.30$. This relatively high elasticity among near-maximum contributors, who tend to be higher earners, is consistent with Bernheim and Scholz (1993), who find that higher-income individuals are more responsive to the after-tax rate of return on savings than lower-income individuals.

The results also suggest that participants with a history of high contribution rates - a group that has substantially higher earnings and wealth - are more likely to take advantage of the higher limit due to the catch-up provision. This finding runs counter to the stated goal of legislators: to raise retirement saving more broadly, and in particular for women hurt by time out of the labor force. But the lack of response to tax incentives among lower savers is consistent with Chetty et al. (2014) and Ramnath (2013). These results suggest that changing 401(k) limits would be unlikely to provide a broad-based solution for low saving rates. Instead, more direct 
policy interventions, such as auto-enrollment tied to auto-escalation, may be necessary to increase retirement saving for this group.

Even concentrating on the previously-constrained older workers induced to contribute more by the catch-up limit, understanding whether the 401(k) saving increase represents new saving requires further research. Researchers have reported conflicting evidence on the extent to which saving through private-sector DB and DC plans crowds out private saving. Poterba, Venti, and Wise (1995), on the one hand, argue that 401(k) plans generate an increase in net retirement saving, while Engen, Gale, and Scholz (1994) find that savers only shift assets. Chetty et al. (2014) suggest that tax expenditures do not increase total saving. Even active savers who respond to tax subsidies only shift assets across savings without increasing the total amount they save. While this study finds that contributors near the maximum are somewhat sensitive to the maximum deferral, it remains unclear whether the increase in 401(k) contributions is a substitution from other accounts or an increase in total saving. Furthermore, previous research suggests that the structure of the employer match heavily influences 401(k) contribution decisions (Engelhardt and Kumar 2007); the SIPP-SSA linked data lacks information on the match, so if matches have changed over time - and in particular around the adoption of catch-up contributions - the results may form an incomplete picture of retirement saving.

The findings of this study also contribute to the literature evaluating the trade-off between further tax expenditures and increased retirement saving. The increase in 401(k) contributions for the 10 percent who were previously constrained may or may not have resulted in a net increase in retirement saving. If it did, further research would be needed to understand whether this increase is sufficient to counteract the additional deadweight loss from the increase in the 401(k) tax expenditure. 


\section{References}

Abowd, John M., Martha Stinson, and Gary Benedetto. 2006. Final Report to the Social Security Administration on the SIPP/SSA/IRS Public Use File Project. Available at: http://www2.vrdc.cornell.edu/news/wp-content/uploads/2007/11/ssafinal.pdf

Benjamin, Daniel J., James J. Choi, and A. Joshua Strickland. 2010. "Social Identity and Preferences.” American Economic Review 100(4): 1913-1928.

Bernheim, B. Douglas. 2002. “Taxation and Savings,” in Handbook of Public Economics Volume 3, Alan J. Auerbach and Martin Feldstein, eds. Amsterdam: North-Holland.

Bernheim, B. Douglas, and John Karl Scholz. 1993. "Private Saving and Public Policy.” In Tax Policy and the Economy, Volume 7, edited by James Poterba. Cambridge, MA: MIT Press.

Cagetti, Marco. 2003. "Wealth Accumulation over the Life Cycle and Precautionary Savings." Journal of Business \& Economic Statistics 21(3): 339-353.

Chetty, Raj, John N. Friedman, Soren Leth-Petersen, Torben Nielsen, and Tore Olsen. 2014. "Active vs. Passive Decisions and Crowdout in Retirement Savings Accounts: Evidence from Denmark.” Working Paper 18565. Cambridge, MA: National Bureau of Economic Research.

Dushi, Irena, Alicia H. Munnell, Geoffrey T. Sanzenbacher, and Anthony Webb. 2015. “Do Households Increase Their Savings When the Kids Leave Home?” Working Paper 201526. Chestnut Hill, MA: Center for Retirement Research at Boston College.

Engelhardt, Gary V., and Anil Kumar. 2007. "Employer Matching and 401(k) Saving: Evidence from the Health and Retirement Study.” Journal of Public Economics 91(10): 1920-1943.

Engen, Eric, William Gale, and John Karl Scholz. 1994. “Do Savings Incentives Work?” Brookings Papers on Economic Activity 1994(1): 85-180.

Gelber, Alexander M. 2011. "How Do 401(k)s Affect Saving? Evidence from Changes in 401(k) Eligibility.” American Economic Journal: Economic Policy 3: 103-122.

Gokhale, Jagadeesh, Laurence J. Kotlikoff, and Mark Warshawsky. 2004. "Life-Cycle Saving, Limits on Contributions to DC plans, and Lifetime Tax Benefits.” In Private Pensions and Public Policies, edited by William G. Gale, John B. Shoven, and Mark J. Warshawsky, 146-188. Washington, DC: Brookings Institution Press.

Heckman, James and Joseph V. Hotz. 1989. “Choosing among Alternative Nonexperimental Methods for Estimating the Impact of Social Programs: The Case of Manpower Training.” Journal of the American Statistical Association 84(408): 862-74. 
Holden, Sarah and Jack VanDerhei. 2001. "Contribution Behavior of 401(k) Plan Participants.” Investment Company Institute Perspective 7(4): 1-20.

Holden, Sarah, Kathy Ireland, Vicky Leonard-Chambers, and Michael Bogdan. 2005. "The Individual Retirement Account at Age 30: A Retrospective.” Investment Company Institute Perspective 11(1): 1-24.

Hubbard, R. Glenn. 1986. "Pension Wealth and Individual Saving: Some New Evidence.” Journal of Money, Credit, and Banking 18(2): 167-178.

Johnston, David Cay. 2001. “Tax Bill Expands Limits on Retirement Savings.” (May 28). New York, NY: The New York Times.

Joint Committee on Taxation. 2015. Estimates of Federal Tax Expenditures for Fiscal Years 2015-2019. Washington, DC: U.S. Government Printing Office.

Joulfaian, David and David P. Richardson. 2001. "Who Takes Advantage of Tax-Deferred Saving Programs? Evidence from Federal Income Tax Data." National Tax Journal 54(3): 669-688.

Kawachi, Janette, Karen E. Smith, and Eric J. Toder. 2005. "Making Maximum Use of TaxDeferred Retirement Accounts.” Working Paper 2005-19. Chestnut Hill, MA: Center for Retirement Research at Boston College.

King, Mervyn A. and L-D. L. Dicks-Mireaux. 1982. "Asset Holdings and the Life-Cycle.” Economic Journal 92(366): 247-267.

Lavecchia, Adam M. 2015. "Did the 'Catch-Up’ Provision Raise Retirement Saving? Evidence from a Regression Discontinuity Design.” Working Paper. Toronto, Ontario, Canada: University of Toronto Department of Economics.

Love, David A. 2007. "What Can the Life-Cycle Model Tell Us About 401(k) Contributions and Participation?” Journal of Pension Economics and Finance 6(2): 147-185.

Milligan, Kevin. 2003. "How Do Contribution Limits Affect Contributions to Tax-Preferred Savings Accounts?” Journal of Public Economics 87: 253-281.

Munnell, Alicia H., Laura Quinby, and Anthony Webb. 2012. "What's the Tax Advantage of 401(k)s?” Issue in Brief 12-4. Chestnut Hill, MA: Center for Retirement Research at Boston College.

Munnell, Alicia H. and Annika Sundén. 2004. Coming Up Short: The Challenge of 401(k) Plans. Washington, DC: Brookings Institution Press. 
Orszag, Peter R. 2004. Progressivity and Saving: Fixing the Nation's Upside-Down Incentives for Saving. Testimony before the House Committee on Education and the Workforce, February 25, 2004. Washington, DC.

Poterba, James, Steven Venti, and David Wise. 1995. “Do 401(k) Contributions Crowd Out Other Personal Saving?” Journal of Public Economics 58(1): 1-32.

Poterba, James M., Steven F. Venti, and David A. Wise. 2008. "New Estimates of the Future Path of 401(k) Assets.” In Tax Policy and the Economy, Volume 22, edited by James M. Poterba. Chicago, IL: University of Chicago Press.

Prudential Financial. 2003. “IRS Issues Final Catch-Up Contribution Rules.” Prudential Retirement Pension Analyst, August. Newark, NJ: The Prudential Insurance Company of America.

Ramnath, Shanthi. 2013. “Taxpayers' Responses to Tax-Based Incentives for Retirement Savings: Evidence from the Saver’s Credit Notch.” Journal of Public Economics 101: 7793.

U.S. Department of Labor. 2013. Private Pension Plan Bulletin: Abstract of 2011 Form 5500 Annual Reports. Washington, DC: U.S. Department of Labor Employee Benefits Security Administration.

The Vanguard Group. 2015. “How America Saves 2015: A Report on Vanguard 2014 Defined Contribution Data.” Valley Forge, PA. Available at: https://institutional.vanguard.com/VGApp/iip/site/institutional/clientsolutions/dc/howame ricasaves, last accessed December 21, 2015.

Wu, April Yanyuan and Matthew S. Rutledge. 2014. "Lower-income Individuals Without Pension: Who Misses Out and Why?” Working Paper 2014-2. Chestnut Hill, MA: Center for Retirement Research at Boston College. 
Table 1. 401(k) Deferral Limits by Age

\begin{tabular}{|c|c|c|c|c|c|c|}
\hline \multirow{2}{*}{ Year } & \multirow{2}{*}{$\begin{array}{l}\text { Nominal } \\
\text { limit }\end{array}$} & \multirow{2}{*}{$\begin{array}{l}\text { Catch-up } \\
\text { limit }\end{array}$} & \multicolumn{2}{|c|}{ Real (2005\$) limit } & \multicolumn{2}{|c|}{ Real YoY increase } \\
\hline & & & Age $<50$ & Age $\geq 50$ & Age $<50$ & Age $\geq 50$ \\
\hline 1999 & $\$ 10,000$ & $\$ 0$ & $\$ 11,722$ & $\$ 11,722$ & $-2.1 \%$ & $-2.1 \%$ \\
\hline 2000 & 10,500 & 0 & 11,907 & 11,907 & 1.6 & 1.6 \\
\hline 2001 & 10,500 & 0 & 11,581 & 11,581 & -2.7 & -2.7 \\
\hline 2002 & 11,000 & 1,000 & 11,942 & 13,027 & 3.1 & 12.5 \\
\hline 2003 & 12,000 & 2,000 & 12,735 & 14,857 & 6.6 & 14.0 \\
\hline 2004 & 13,000 & 3,000 & 13,438 & 16,539 & 5.5 & 11.3 \\
\hline 2005 & 14,000 & 4,000 & 14,000 & 18,000 & 4.2 & 8.8 \\
\hline 2006 & 15,000 & 5,000 & 14,532 & 19,376 & 3.8 & 7.6 \\
\hline 2007 & 15,500 & 5,000 & 14,597 & 19,306 & 0.4 & -0.4 \\
\hline 2008 & 15,500 & 5,000 & 14,061 & 18,596 & -3.7 & -3.7 \\
\hline 2009 & 16,500 & 5,500 & 15,016 & 20,021 & 6.8 & 7.7 \\
\hline 2010 & 16,500 & 5,500 & 14,774 & 19,699 & -1.6 & -1.6 \\
\hline 2011 & 16,500 & 5,500 & 14,324 & 19,099 & -3.0 & -3.0 \\
\hline 1999-2001 avg & 10,333 & 0 & 11,737 & 11,737 & -1.1 & -1.1 \\
\hline 2002-2011 avg & 14,550 & 4,150 & 13,942 & 17,852 & 2.2 & 5.3 \\
\hline $\begin{array}{c}\% \text { change, '99-'01 } \\
\text { to '02-'11 }\end{array}$ & & & $18.8 \%$ & $52.1 \%$ & & \\
\hline 2016 & 18,000 & 6,000 & 14,758 & 19,678 & 2.2 & 3.7 \\
\hline
\end{tabular}

Notes: Real amounts adjusted for the annual average Consumer Price Index for All Urban Consumers. Dollar values are rounded to the nearest dollar.

Source: Authors' calculations from the Internal Revenue Service.

Table 2. Sample Refinement

\begin{tabular}{lc}
\hline Criterion & Unique persons remaining \\
\hline Full SIPP Completed Data Files sample & 783,781 \\
Ever between ages 40-65 in 1999-2011 & 366,254 \\
Valid match to SSA data & 289,756 \\
Between ages 46-53 at some point in 1999-2011 & 180,793 \\
$\begin{array}{l}\text { Earned four Social Security credits in each year at } \\
\quad \text { ages 46-53 }\end{array}$ & 86,530 \\
No work-preventing health condition, and did not & \\
$\quad$ die at ages 46-53 & 85,170 \\
\hline
\end{tabular}

Source: Authors’ calculations from the SIPP Completed Data Files (1999-2011). 
Table 3. Summary Statistics for Full Sample and Maximum Contributors

\begin{tabular}{lcc}
\hline Characteristic & Full sample & $\begin{array}{c}\text { Maximum } \\
\text { contributors }\end{array}$ \\
\hline Deferred earnings & $\$ 2,418$ & $\$ 9,903$ \\
Earnings & $\$ 60,172$ & $\$ 164,828$ \\
Net worth & $\$ 214,944$ & $\$ 474,762$ \\
Male & $52.2 \%$ & $70.3 \%$ \\
Married & 73.4 & 79.8 \\
Ever had children & 77.9 & 70.9 \\
Children ages 0-17 & 44.5 & 41.3 \\
Children ages 18-24 & 29.1 & 25.7 \\
Black & 9.2 & 3.3 \\
Other race & 4.5 & 6.9 \\
Hispanic & 6.0 & 2.5 \\
Foreign born & 8.6 & 10.3 \\
Less than HS & 5.5 & 0.7 \\
HS degree only & 27.9 & 7.3 \\
Some college & 32.4 & 18.4 \\
College degree & 21.1 & 36.3 \\
Graduate degree & 13.1 & 37.3 \\
Homeowner & 78.6 & 88.5 \\
Blue collar & 29.9 & 33.2 \\
Work limited & 8.2 & 4.8 \\
\hline Number of observations & 225,401 & 19,975 \\
Proportion of full sample & & $8.9 \%$ \\
\hline
\end{tabular}

Source: Authors' calculations from the SIPP Completed Data Files (1999-2011). 
Table 4. Triple-Differences Regression Results

\begin{tabular}{|c|c|c|}
\hline Dependent variable & $\frac{\text { Deferred amount }}{(1)}$ & $\frac{\text { Deferred percentage }}{(2)}$ \\
\hline Mean of the dependent variable & 2900.4 & 0.042 \\
\hline Year $\geq 2002$ & $\begin{array}{l}191.5^{* * *} \\
(30.9)\end{array}$ & $\begin{array}{r}0.0005 \\
(0.0005)\end{array}$ \\
\hline Age 50+ & $\begin{array}{r}27.4 \\
(30.8)\end{array}$ & $\begin{array}{l}0.0016^{* * *} \\
(0.0006)\end{array}$ \\
\hline Ever previously at $401(\mathrm{k})$ limit & $\begin{array}{l}5697.4^{* * *} \\
(104.0)\end{array}$ & $\begin{array}{l}0.0343^{* * * *} \\
(0.0015)\end{array}$ \\
\hline$($ Age $50+) \times($ Year $\geq 2002)$ & $\begin{array}{l}137.6^{* * *} \\
(35.1)\end{array}$ & $\begin{array}{l}0.0017^{* * * *} \\
(0.0006)\end{array}$ \\
\hline$($ Age $50+) \times($ At limit $)$ & $\begin{array}{l}-366.0 * * \\
(164.0)\end{array}$ & $\begin{array}{l}-0.0049 * * \\
(0.0022)\end{array}$ \\
\hline (At limit) $\times($ Year $\geq 2002)$ & $\begin{array}{l}1166.0^{* * *} \\
(118.3)\end{array}$ & $\begin{array}{l}0.0044^{* * *} \\
(0.0016)\end{array}$ \\
\hline$($ Age $50+) \times($ Year $\geq 2002) \times($ At limit $)$ & $\begin{array}{l}817.8 * * * \\
(193.6)\end{array}$ & $\begin{array}{l}0.0092 * * * \\
(0.0025)\end{array}$ \\
\hline DB pension in SIPP window & $\begin{array}{l}219.3^{* * *} \\
(34.9)\end{array}$ & $\begin{array}{l}0.0044^{* * *} \\
(0.0006)\end{array}$ \\
\hline Lowest earnings tercile & $\begin{array}{c}-2817.5 * * * \\
(27.9)\end{array}$ & $\begin{array}{l}-0.0276^{* * *} \\
(0.0005)\end{array}$ \\
\hline Middle earnings tercile & $\begin{array}{c}-1974.4^{* * *} \\
(24.4)\end{array}$ & $\begin{array}{l}-0.0102^{* * *} \\
(0.0004)\end{array}$ \\
\hline Bottom wealth quartile & $\begin{array}{l}-396.5^{* * *} \\
(43.0)\end{array}$ & $\begin{array}{l}-0.0065 * * * \\
(0.0007)\end{array}$ \\
\hline 2nd wealth quartile & $\begin{array}{l}-287.4^{* * *} \\
(33.3)\end{array}$ & $\begin{array}{l}-0.0038 * * * \\
(0.0005)\end{array}$ \\
\hline 3rd wealth quartile & $\begin{array}{l}-166.7 * * * \\
(32.5)\end{array}$ & $\begin{array}{l}-0.0017 * * * \\
(0.0005)\end{array}$ \\
\hline Married & $\begin{array}{l}181.5^{* * *} \\
(58.4)\end{array}$ & $\begin{array}{l}0.0030 * * * \\
(0.0009)\end{array}$ \\
\hline Children ages 0-17 & $\begin{array}{l}-182.5^{* * * *} \\
(24.4)\end{array}$ & $\begin{array}{l}-0.0035 * * * \\
(0.0004)\end{array}$ \\
\hline Children ages 18-24 & $\begin{array}{r}-40.3 \\
(25.4)\end{array}$ & $\begin{array}{l}-0.0011 * * * \\
(0.0004)\end{array}$ \\
\hline $\begin{array}{l}\text { Sample size } \\
\mathrm{R}^{2}\end{array}$ & $\begin{array}{r}299,599 \\
0.490\end{array}$ & $\begin{array}{r}299,599 \\
0.173\end{array}$ \\
\hline
\end{tabular}

Notes: Models also include race and education categories; indicators for sex, Hispanic origin, foreign born, homeownership, having a working spouse, and blue collar occupation; Census region and year dummies; and a constant. Significance is indicated to the 1-percent level $(* * *)$ and 5-percent level $(* *)$.

Source: Authors' calculations from the SIPP Completed Data Files (1999-2011). 
Table 5. Triple-Differences Regression Results with Separate Age Estimates

\begin{tabular}{|c|c|c|}
\hline \multirow{2}{*}{ Dependent variable } & Deferred amount & Deferred percentage \\
\hline & $(1)$ & $(2)$ \\
\hline Mean of the dependent variable & 2900.4 & 0.042 \\
\hline \multirow[t]{2}{*}{ Year $\geq 2002$} & $183.2^{* * *}$ & 0.0007 \\
\hline & $(37.9)$ & $(0.0006)$ \\
\hline \multirow[t]{2}{*}{ Age 47} & 22.2 & $0.0009 * *$ \\
\hline & $(25.3)$ & $(0.0004)$ \\
\hline \multirow[t]{2}{*}{ Age 48} & 27.8 & $0.0017 * * *$ \\
\hline & $(32.5)$ & $(0.0006)$ \\
\hline \multirow[t]{2}{*}{ Age 49} & 50.4 & $0.0021 * * *$ \\
\hline & $(37.7)$ & $(0.0007)$ \\
\hline \multirow[t]{2}{*}{ Age 50} & 48.9 & $0.0022 * * *$ \\
\hline & $(38.9)$ & $(0.0007)$ \\
\hline \multirow[t]{2}{*}{ Age 51} & $75.8 *$ & $0.0031 * * *$ \\
\hline & $(41.3)$ & $(0.0007)$ \\
\hline \multirow[t]{2}{*}{ Age 52} & 61.0 & $0.0032 * * *$ \\
\hline & $(43.6)$ & $(0.0008)$ \\
\hline \multirow[t]{2}{*}{ Age 53} & 26.5 & $0.0026 * * *$ \\
\hline & $(46.7)$ & $(0.0008)$ \\
\hline \multirow[t]{2}{*}{ Ever previously at $401(\mathrm{k})$ limit } & $6073.1^{* * *}$ & $0.0360 * * *$ \\
\hline & $(152.3)$ & $(0.0021)$ \\
\hline \multirow[t]{2}{*}{$($ Age 47$) \times($ Year $\geq 2002)$} & -2.5 & -0.0005 \\
\hline & $(29.3)$ & $(0.0005)$ \\
\hline \multirow[t]{2}{*}{$($ Age 48$) \times($ Year $\geq 2002)$} & 5.5 & -0.0008 \\
\hline & $(37.6)$ & $(0.0006)$ \\
\hline \multirow[t]{2}{*}{$($ Age 49$) \times($ Year $\geq 2002)$} & -0.5 & -0.0004 \\
\hline & $(43.5)$ & $(0.0008)$ \\
\hline \multirow[t]{2}{*}{$($ Age 50$) \times($ Year $\geq 2002)$} & 21.9 & 0.0000 \\
\hline & $(45.0)$ & $(0.0008)$ \\
\hline \multirow[t]{2}{*}{ (Age 51$) \times($ Year $\geq 2002)$} & 72.6 & 0.0004 \\
\hline & $(47.6)$ & $(0.0008)$ \\
\hline \multirow[t]{2}{*}{$($ Age 52$) \times($ Year $\geq 2002)$} & $151.3^{* * *}$ & 0.0014 \\
\hline & $(50.1)$ & $(0.0009)$ \\
\hline \multirow[t]{2}{*}{$($ Age 53$) \times($ Year $\geq 2002)$} & $218.9 * * *$ & $0.0028 * * *$ \\
\hline & $(53.4)$ & $(0.0009)$ \\
\hline \multirow[t]{2}{*}{$($ Age 47$) \times($ Year $\geq 2002) \times($ At limit $)$} & 109.4 & 0.0029 \\
\hline & $(181.0)$ & $(0.0024)$ \\
\hline \multirow[t]{2}{*}{$($ Age 48$) \times($ Year $\geq 2002) \times($ At limit $)$} & 372.7 & 0.0021 \\
\hline & $(227.2)$ & $(0.0031)$ \\
\hline \multirow[t]{2}{*}{$($ Age 49$) \times($ Year $\geq 2002) \times($ At limit $)$} & 243.2 & 0.0026 \\
\hline & $(253.2)$ & $(0.0035)$ \\
\hline \multirow[t]{2}{*}{$($ Age 50$) \times($ Year $\geq 2002) \times($ At limit $)$} & $878.3^{* * *}$ & $0.0076^{* *}$ \\
\hline & $(257.7)$ & $(0.0035)$ \\
\hline
\end{tabular}


Table 5. Triple-Differences Regression Results with Separate Age Estimates (cont’d)

\begin{tabular}{lcc}
\hline \multirow{2}{*}{ Dependent variable } & Deferred amount & Deferred percentage \\
\cline { 2 - 3 }$($ Age 51) $\times($ Year $\geq 2002) \times($ At limit $)$ & $1417.7^{* * *}$ & $(2)$ \\
& $(277.6)$ & $0.0123^{* * *}$ \\
$($ Age 52 $) \times($ Year $\geq 2002) \times($ At limit $)$ & $1143.4^{* * *}$ & $0.0037)$ \\
& $(281.0)$ & $(0.0037)$ \\
$($ Age 53) $\times($ Year $\geq 2002) \times($ At limit $)$ & $852.5^{* * *}$ & $0.0114^{* * *}$ \\
& $(283.8)$ & $(0.0037)$ \\
\hline Sample size & 299,599 & 299,599 \\
$\mathrm{R}^{2}$ & 0.491 & 0.174 \\
\hline
\end{tabular}

Notes: Models include same controls as the models in Table 4. Significance is indicated to the 1-percent level (***), 5-percent level (**) and 10-percent level (*).

Source: Authors’ calculations from the SIPP Completed Data Files (1999-2011).

Table 6. Triple-Differences Regression Results with Individual Fixed Effects

\begin{tabular}{lcc}
\hline \multirow{2}{*}{ Dependent variable } & Deferred amount & Deferred percentage \\
\cline { 2 - 3 } Mean of the dependent variable & $(1)$ & $(2)$ \\
\hline Year $\geq 2002$ & 9324.9 & 0.039 \\
Age 50+ & $(31.3)$ & $0.0120^{* * *}$ \\
Ever previously at 401(k) limit & $58.5^{* * *}$ & $(0.0005)$ \\
& $(16.2)$ & $0.0011^{* * *}$ \\
(Age 50+) $($ Year $\geq 2002)$ & $1643.4^{* * *}$ & $0.0003)$ \\
& $(145.8)$ & $\left(0.00124^{* * *}\right.$ \\
Age 50+) $\times($ At limit) & $-42.6^{* *}$ & -0.0004 \\
& $(17.2)$ & $(0.0003)$ \\
$($ At limit $) \times($ Year $\geq 2002)$ & $-644.9^{* * *}$ & $-0.0088^{* * *}$ \\
$($ Age 50+) $\times($ Year $\geq 2002) \times($ At limit $)$ & $(121.6)$ & $(0.0012)$ \\
& 102.3 & -0.0015 \\
Sample size & $(102.0)$ & $(0.0010)$ \\
$\mathrm{R}^{2}$ & $1182.5^{* * *}$ & $0.0089^{* * *}$ \\
\hline
\end{tabular}

Notes: Models also include marital status, presence of children (by age), net worth quintiles, earnings terciles, year dummies, and a constant. Significance is indicated to the 1-percent level $(* * *)$ and 5-percent level (**).

Source: Authors' calculations from the SIPP Completed Data Files (1999-2011). 
Table 7. Share of 50+ Contributors Taking Advantage of Catch-Up Contributions, by Past Contributions

\begin{tabular}{lcccc}
\hline & & \multicolumn{3}{c}{ Tercile of cumulative contributions in prior years } \\
\cline { 3 - 5 } & All & Lowest & Middle & Highest \\
\hline All & 7.0 & 1.3 & 1.1 & 12.3 \\
Men & 9.1 & 1.4 & 1.2 & 14.2 \\
Women & 4.8 & 1.2 & 1.1 & 9.5 \\
\hline
\end{tabular}

Note: Includes both those who contribute over the pre-50 maximum and those who increase their contribution by the amount of the increase in the catch-up limit.

Source: Authors’ calculations from the SIPP Completed Data Files (1999-2011).

Table 8. Triple-Differences Regression Results, Selected Sub-Samples

\begin{tabular}{|c|c|c|c|c|c|}
\hline Dependent variable & Deferre & I amount & Deferred & percentage & \\
\hline Coefficient & $\begin{array}{c}(\text { At limit }) \\
\times(\text { Year } \geq 2002)\end{array}$ & $\begin{array}{c}\text { (Age 50+) } \\
\times(\text { Year } \geq 2002) \times \\
(\text { At limit })\end{array}$ & $\begin{array}{l}\text { (At limit) } \\
\times(\text { Year } \geq \\
2002)\end{array}$ & $\begin{array}{c}\text { (Age } 50+) \times \\
(\text { Year } \geq 2002) \\
\times(\text { At limit })\end{array}$ & Sample size \\
\hline Men & $\begin{array}{l}1182.1 * * * \\
(136.6)\end{array}$ & $\begin{array}{l}716.4 * * * \\
(223.3)\end{array}$ & $\begin{array}{l}0.0063 * * * \\
(0.0016)\end{array}$ & $\begin{array}{l}0.0082 * * * \\
(0.0026)\end{array}$ & 173,062 \\
\hline Women & $\begin{array}{l}1130.5 * * * \\
(237.1)\end{array}$ & $\begin{array}{l}990.5 * * \\
(391.1)\end{array}$ & $\begin{array}{r}-0.0039 \\
(0.0039)\end{array}$ & $\begin{array}{r}0.0092 \\
(0.0065)\end{array}$ & 126,707 \\
\hline No kids & $\begin{array}{l}1073.9 * * * \\
(247.4)\end{array}$ & $\begin{array}{r}556.2 \\
(515.3)\end{array}$ & $\begin{array}{c}0.0069 * * \\
(0.0034)\end{array}$ & $\begin{array}{r}0.0015 \\
(0.0066)\end{array}$ & 52,010 \\
\hline Children 0-17 & $\begin{array}{l}1169.7 * * * \\
(157.8)\end{array}$ & $\begin{array}{l}753.2 \text { *** } \\
(234.4)\end{array}$ & $\begin{array}{l}0.0056 \text { *** } \\
(0.0020)\end{array}$ & $\begin{array}{c}0.0072 * * \\
(0.0030)\end{array}$ & 215,135 \\
\hline Children 18-24 & $\begin{array}{l}1108.8 * * * \\
(139.8)\end{array}$ & $\begin{array}{l}679.1 * * * \\
(241.1)\end{array}$ & $\begin{array}{c}0.0036 \text { ** } \\
(0.0018)\end{array}$ & $\begin{array}{l}0.0086 * * * \\
(0.0030)\end{array}$ & 185,663 \\
\hline Grown kids & $\begin{array}{l}1216.3 * * * \\
(180.3)\end{array}$ & $\begin{array}{l}1113.4 * * * \\
(329.5)\end{array}$ & $\begin{array}{c}0.0041 * \\
(0.0025)\end{array}$ & $\begin{array}{l}0.0140 * * * \\
(0.0042)\end{array}$ & 101,947 \\
\hline Any college & $\begin{array}{l}1240.9 * * * \\
(124.2)\end{array}$ & $\begin{array}{l}745.2 \text { *** } \\
(204.4)\end{array}$ & $\begin{array}{c}0.0036 * * \\
(0.0016)\end{array}$ & $\begin{array}{l}0.0092 * * * \\
(0.0026)\end{array}$ & 200,360 \\
\hline No college & $\begin{array}{r}-89.2 \\
(373.4)\end{array}$ & $\begin{array}{r}756.6 \\
(719.8)\end{array}$ & $\begin{array}{r}0.0064 \\
(0.0061)\end{array}$ & $\begin{array}{r}-0.0031 \\
(0.0112)\end{array}$ & 99,409 \\
\hline Below median wealth & $\begin{array}{l}1209.2 \text { *** } \\
(127.6)\end{array}$ & $\begin{array}{l}755.9 * * * \\
(209.7)\end{array}$ & $\begin{array}{l}0.0049 * * * \\
(0.0017)\end{array}$ & $\begin{array}{c}0.0078 * * * \\
(0.0027)\end{array}$ & 176,192 \\
\hline Above median wealth & $\begin{array}{l}941.6 \text { *** } \\
(322.7)\end{array}$ & $\begin{array}{r}739.1 \\
(543.3) \\
\end{array}$ & $\begin{array}{r}-0.0031 \\
(0.0043)\end{array}$ & $\begin{array}{c}0.0133^{*} \\
(0.0075)\end{array}$ & 123,577 \\
\hline
\end{tabular}

Note: Models include same controls as the models in Table 4.

Source: Authors' calculations from the SIPP Completed Data Files (1999-2011). 
Table 9. Triple-Differences Regression Results - Total Earnings

\begin{tabular}{lc}
\hline Dependent variable & Total earnings \\
\cline { 2 - 2 } Mean of the dependent variable & $(1)$ \\
\hline Year $\geq 2002$ & 54528.8 \\
Age 50+ & $(827.8)$ \\
Ever previously at 401(k) limit & $-1459.1^{* * * *}$ \\
& $(537.1)$ \\
(Age 50+) $\times($ Year $\geq 2002)$ & $135094.4^{* * *}$ \\
& $(46317.1)$ \\
(Age 50+) $\times($ At limit) & -307.4 \\
& $(529.9)$ \\
(At limit) $\times($ Year $\geq 2002)$ & -35357.6 \\
(Age 50+) $\times($ Year $\geq 2002) \times($ At limit) & $(52380.1)$ \\
DB pension in SIPP window & -59944.3 \\
& $(46847.6)$ \\
Lowest earnings tercile & 21757.4 \\
Middle earnings tercile & $(52898.9)$ \\
Married & -1186.5 \\
Children ages 0-17 & $(2485.5)$ \\
Children ages 18-24 & $-61421.5^{* * *}$ \\
\hline Sample size & $(646.1)$ \\
& $-42586.3^{* * *}$ \\
& $(465.4)$ \\
& $2504.1^{*}$ \\
& $(1478.9)$ \\
& -1054.7 \\
& $(1572.0)$ \\
& -1044.2 \\
& $(967.2)$ \\
\hline
\end{tabular}

Notes: Models also include net worth terciles; race and education categories; indicators for sex, Hispanic origin, foreign born, homeownership, having a working spouse, and blue collar occupation; Census region and year dummies; and a constant. Significance is indicated to the 1-percent level $(* * *)$ and 10-percent level (*). Source: Authors' calculations from the SIPP Completed Data Files (1999-2011). 
Figure 1. Average Deferred Earnings by Age and Year: Workers Who Are Never Near the TaxDeferred Maximum

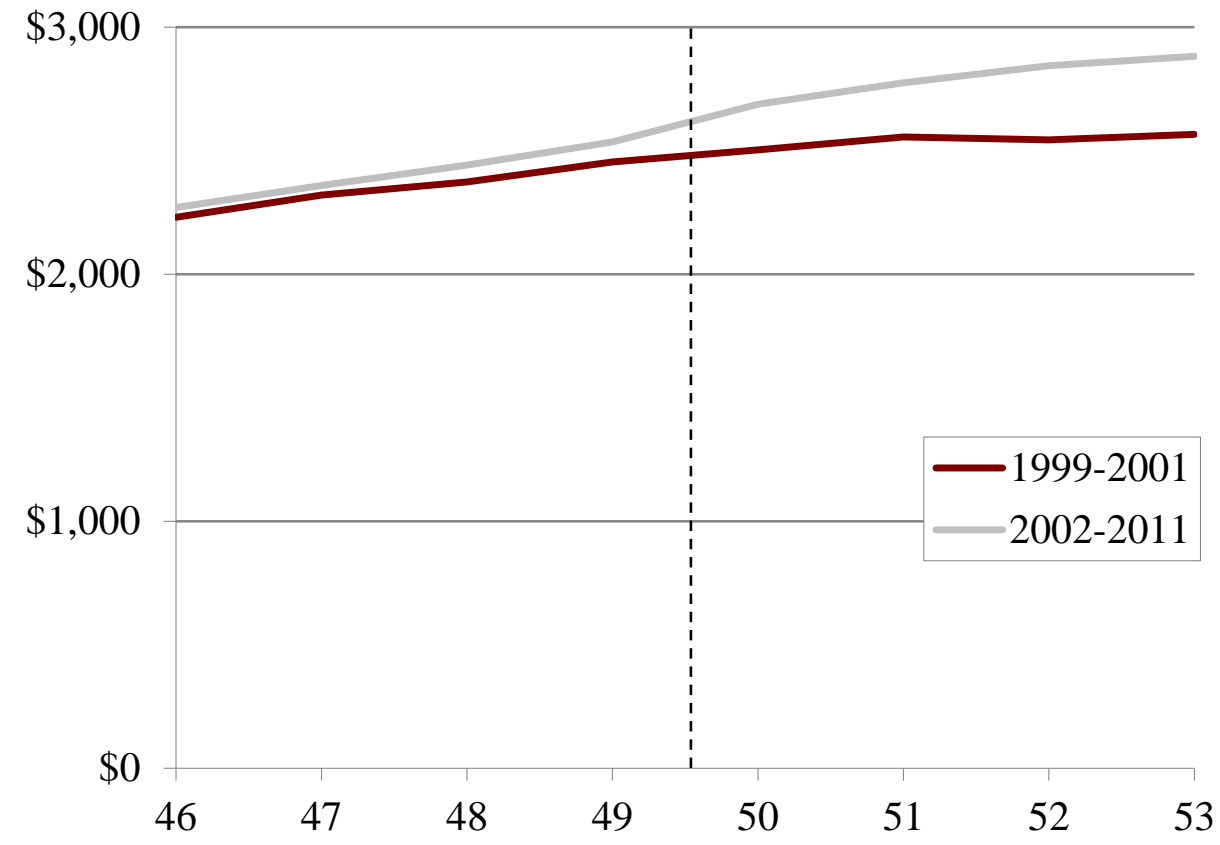

Source: Authors' calculations from the SIPP Completed Data Files (1999-2011).

Figure 2. Average Deferred Earnings by Age and Year: Workers Who Are Ever Near the TaxDeferred Maximum

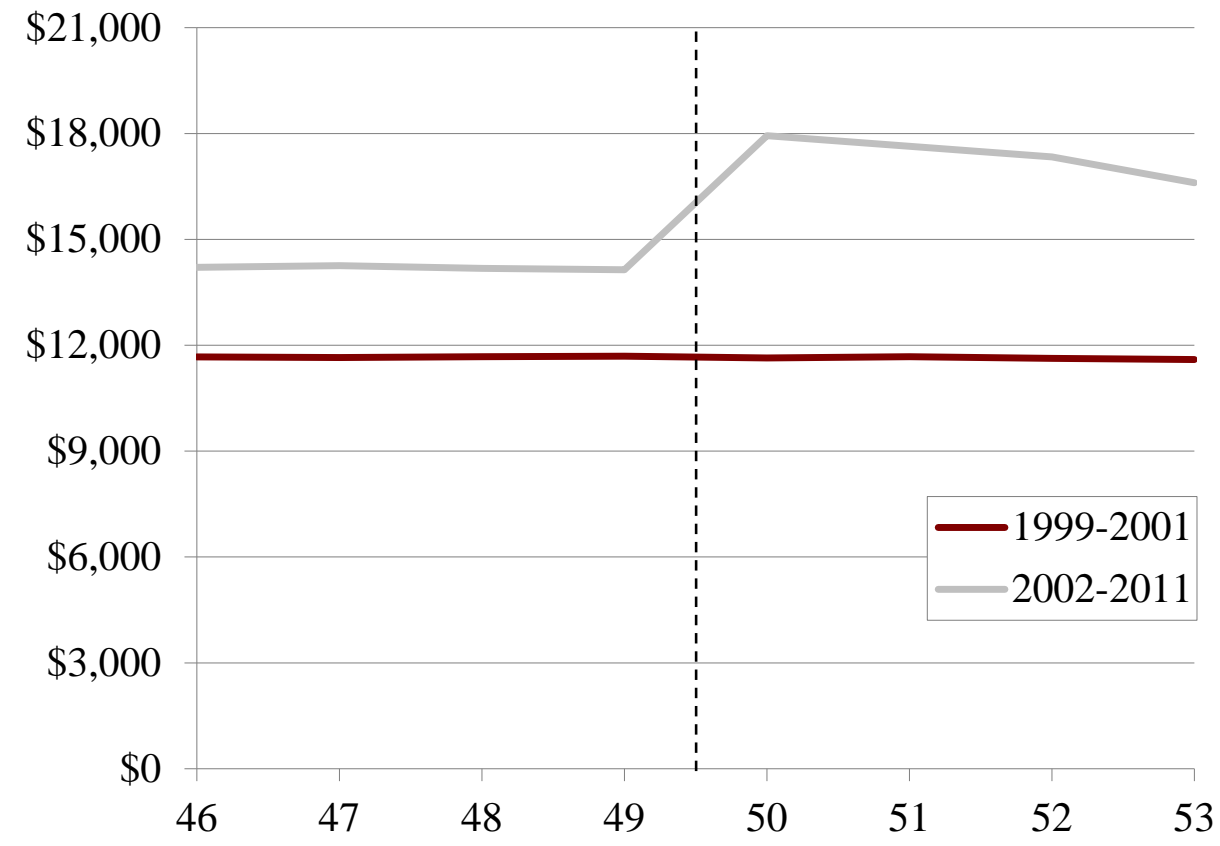

Source: Authors' calculations from the SIPP Completed Data Files (1999-2011). 
Figure 3. Average Deferred Earnings by Year, Age, and Contribution History

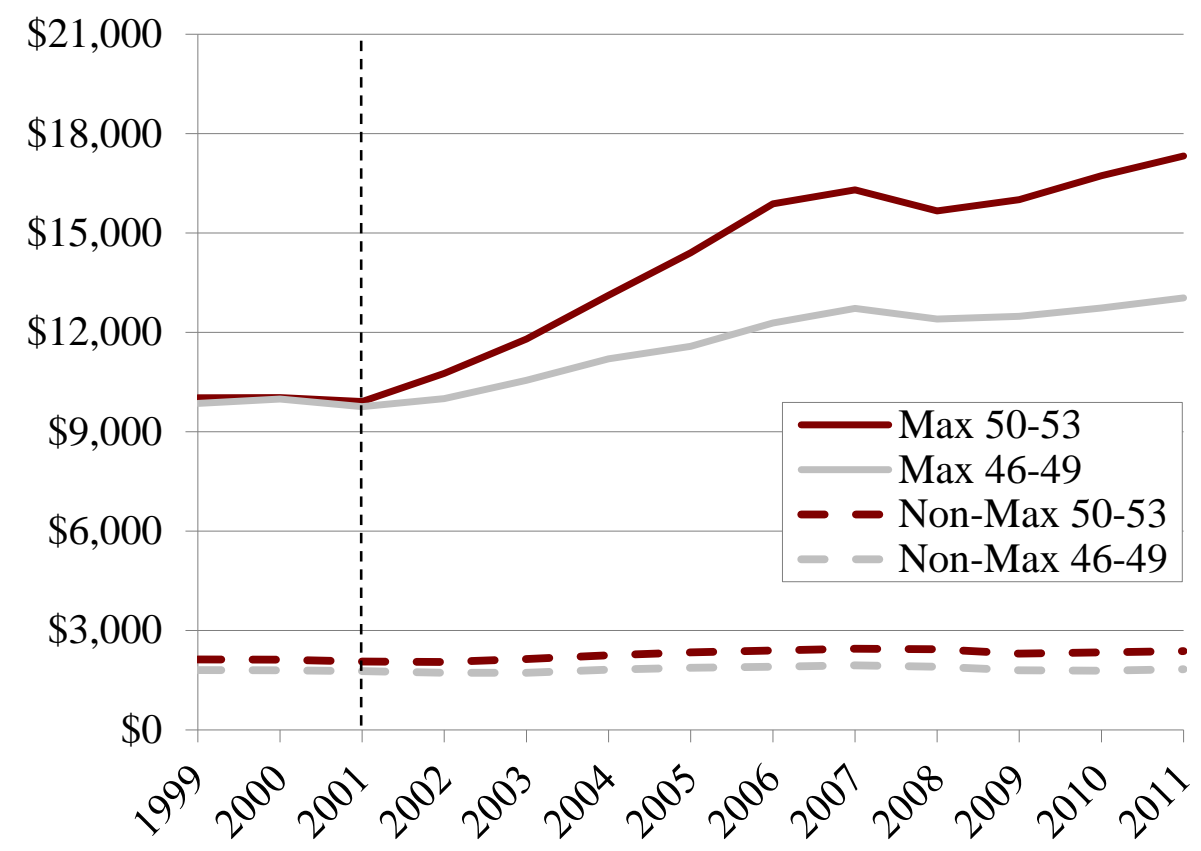

Source: Authors’ calculations from the SIPP Completed Data Files (1999-2011).

Figure 4. Predicted Increase in 401(k) Contributions from 1999-2001 to 2002-2011, 2005 Dollars

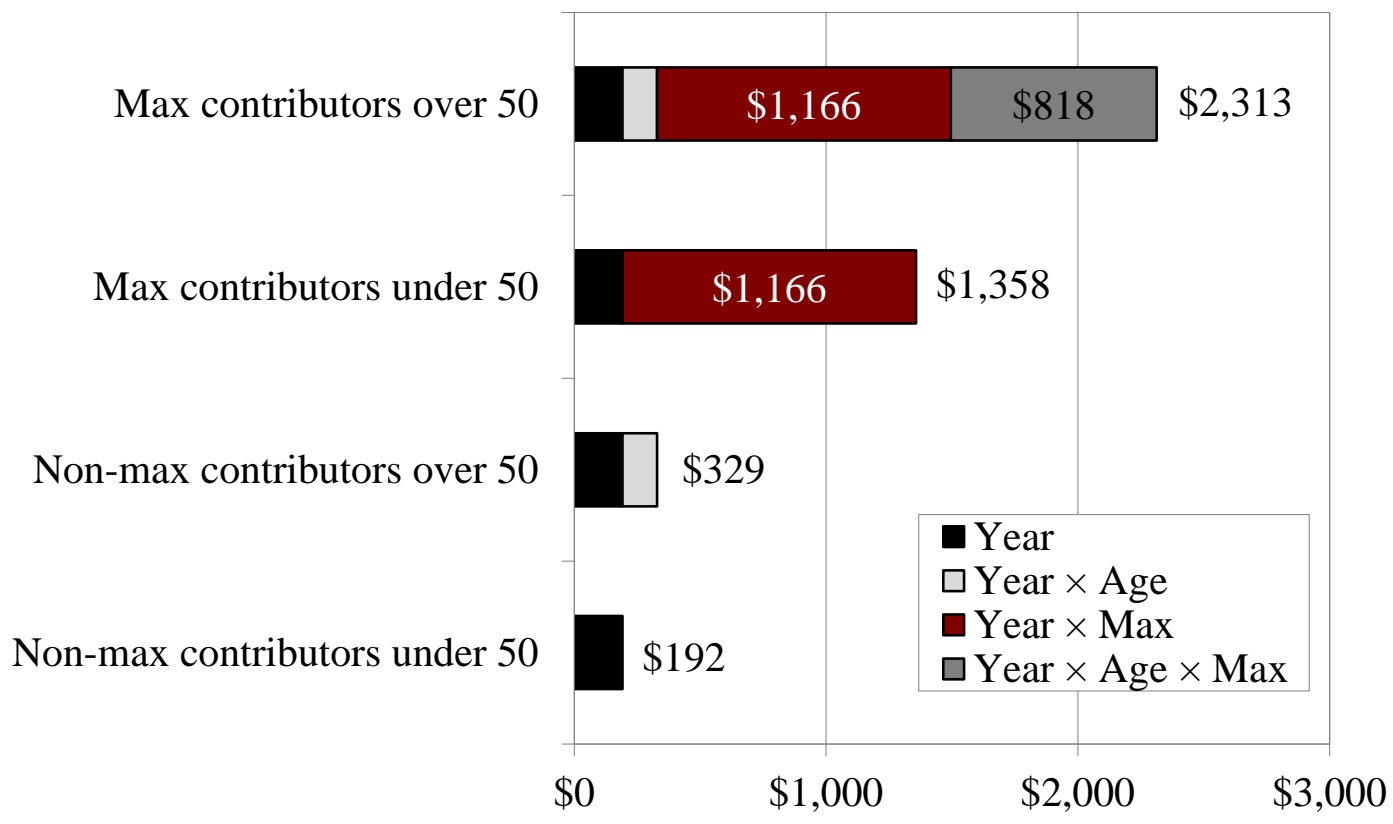

Source: Authors’ estimates from the SIPP Completed Data Files (1999-2011). 
Figure 5a. Predicted Additional Increase in 401(k) Contributions for Maximum Contributors, By Age

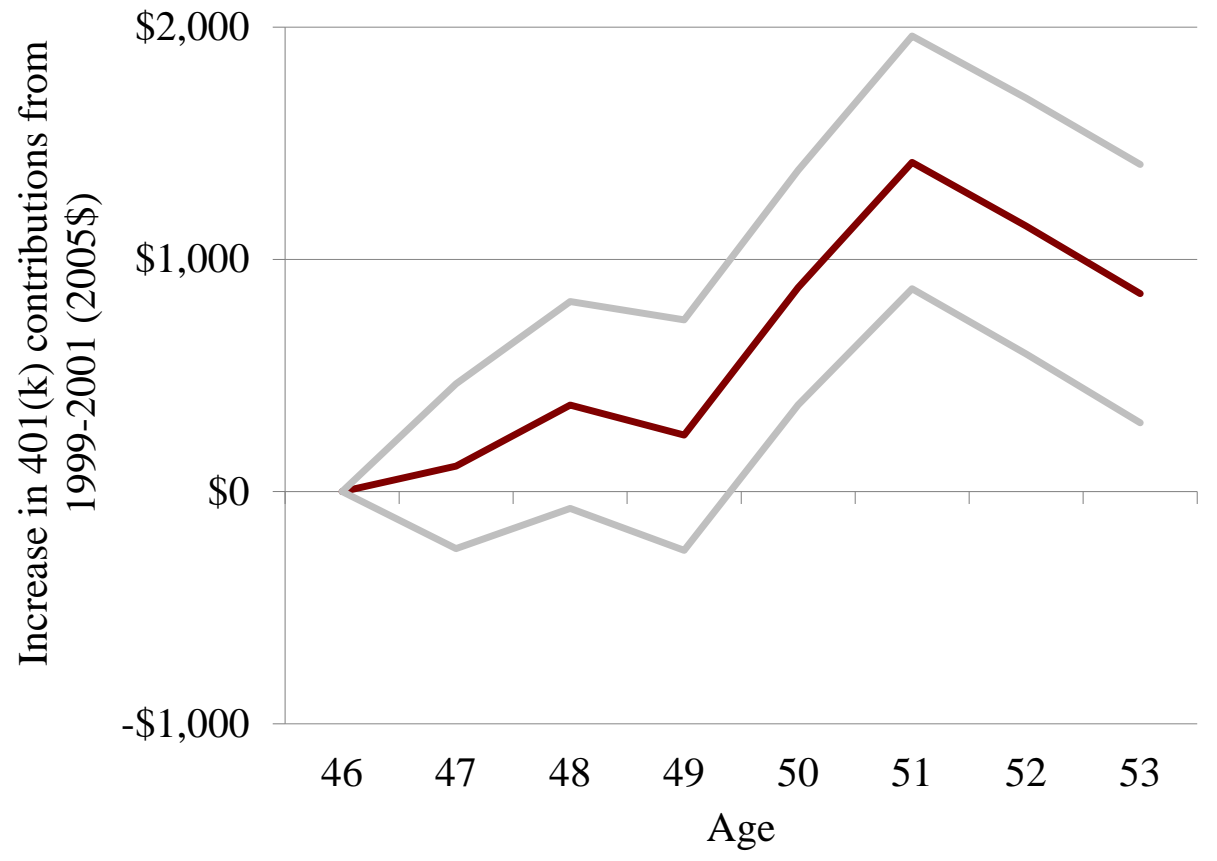

Figure 5b. Predicted Additional Increase in 401(k) Contribution Rate for Maximum Contributors, by Age

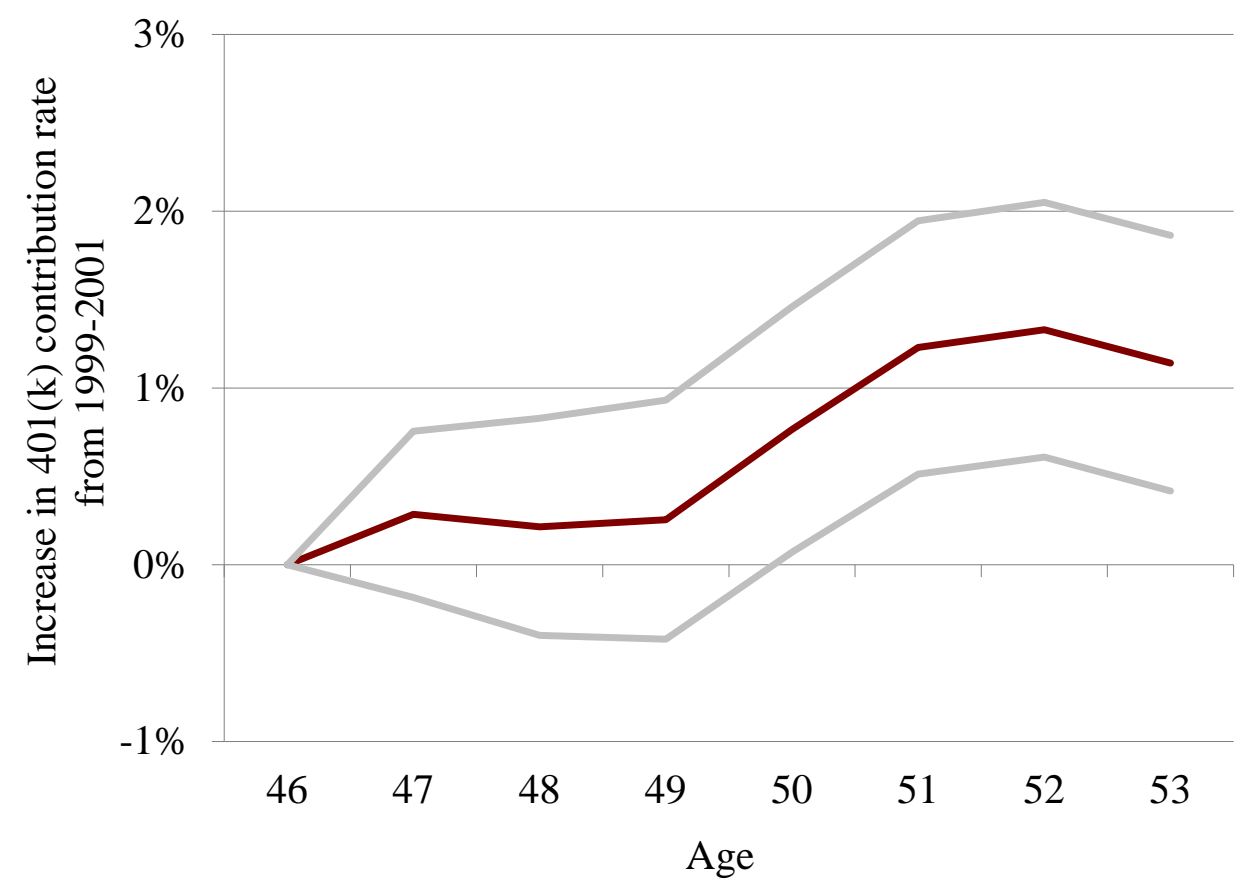

Source: Authors’ estimates from the SIPP Completed Data Files (1999-2011). 
Figure 6a. Predicted Additional Increase in 401(k) Contributions for Maximum Contributors 50 and Older (Relative to Age 46-49), by Year

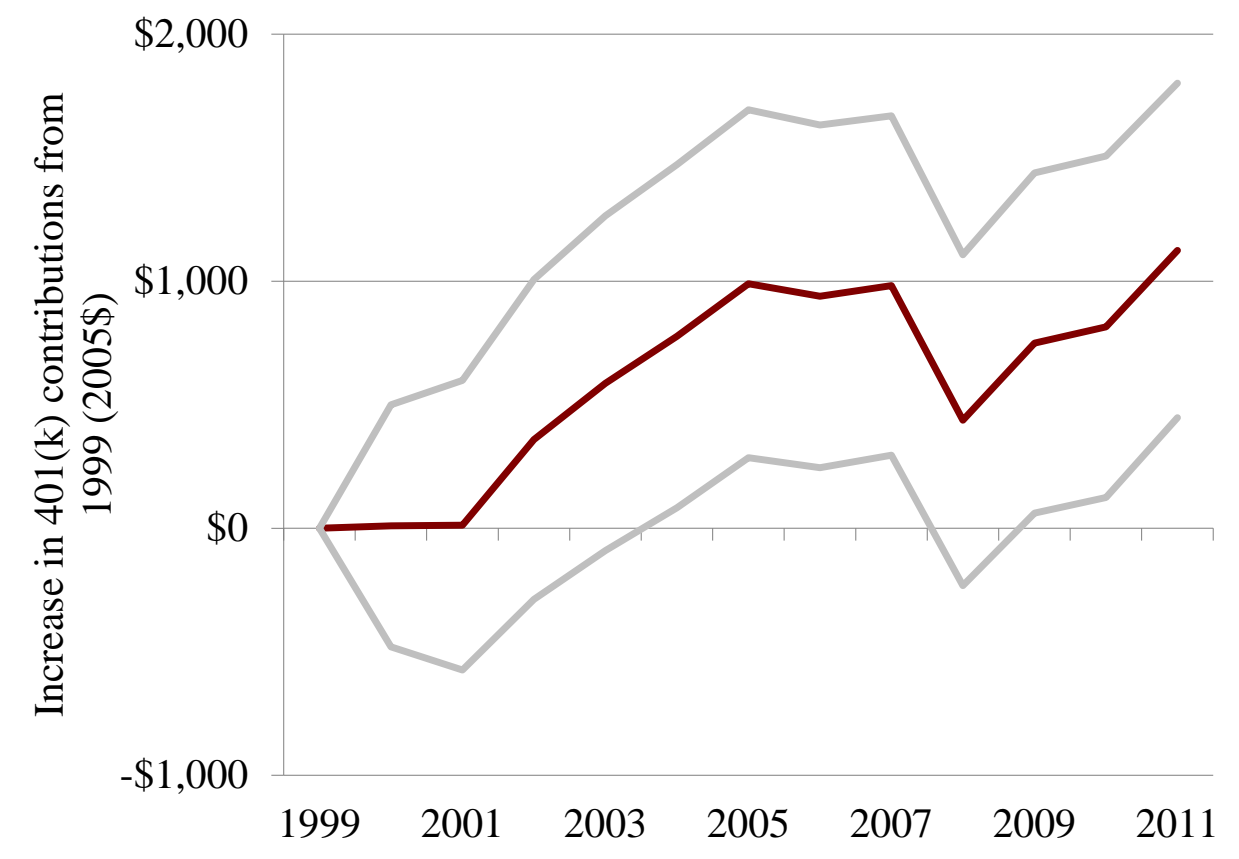

Figure 6b. Predicted Additional Increase in 401(k) Contribution Rate for Maximum Contributors 50 and Older (Relative to Age 46-49), by Year

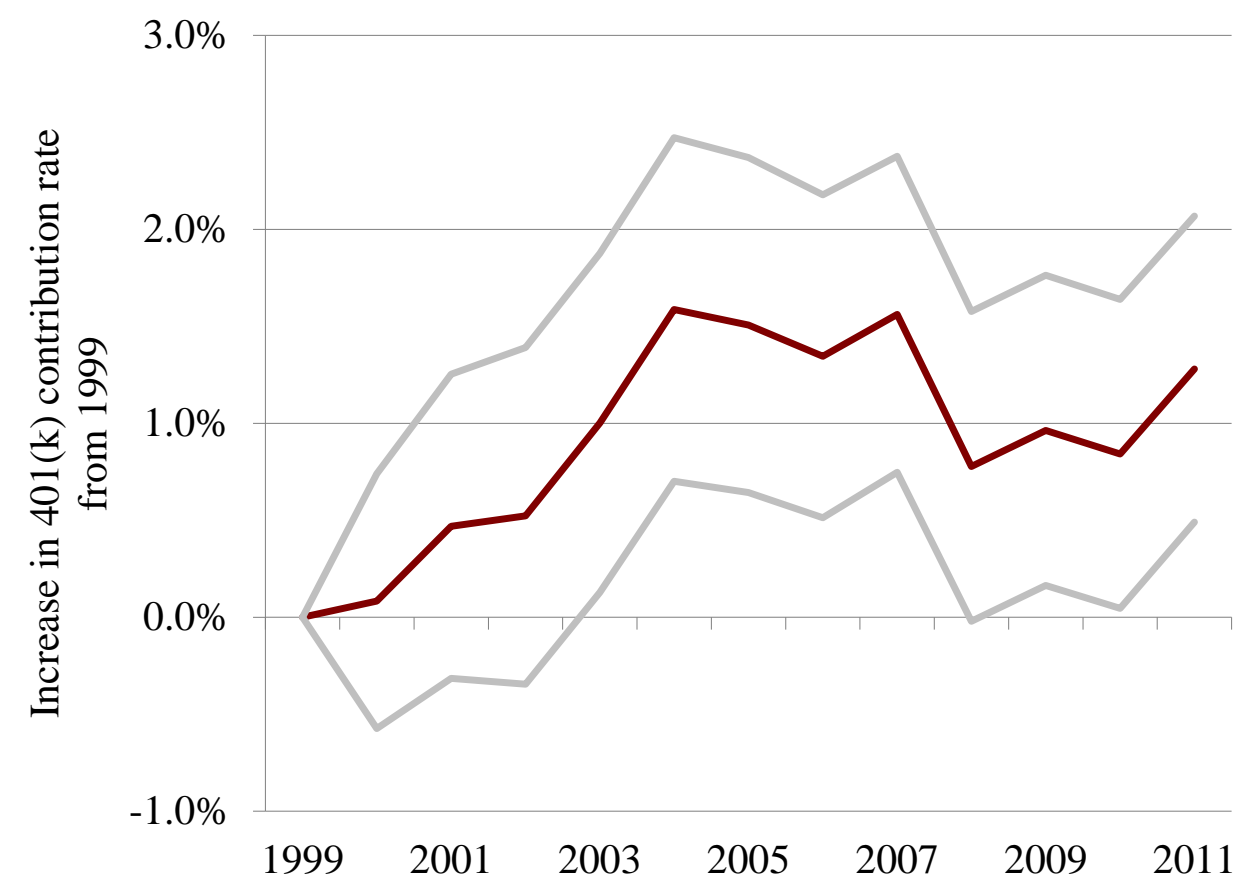

Source: Authors' estimates from the SIPP Completed Data Files (1999-2011). 


\section{Appendix}

Table A.1. Frequency Contributing Near the Maximum 401(k) Contribution

\begin{tabular}{lccc}
\hline Years at ages 46-53 in 1990-2011 & Number & Percent & $\begin{array}{c}\text { Percent ever } \\
\text { at max }\end{array}$ \\
\hline Never & 205,920 & $91.1 \%$ & \\
$1-3$ & 10,614 & 4.7 & $53.0 \%$ \\
$4-7$ & 4,789 & 2.1 & 23.9 \\
All (maximum of 8) & 4,621 & 2.0 & 23.1 \\
\hline
\end{tabular}

Note: Participants are "near" the maximum if their deferred earnings are within 10 percent of that year's tax-deferred limit.

Source: Authors’ calculations from the SIPP Completed Data Files (1999-2011). 